\title{
التباين المكاني لقيم هلوحة التربة في قضائي بدرة والحي
}

أ.د. نـاصر والبي فربيم/ كلية التربية/ جامعة واسط

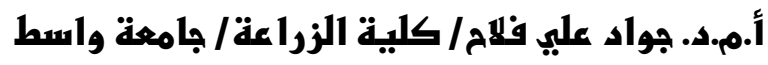
الباهث عباسر طراد ساجت زغير

الخغلاهة:

تناول البحث تملح التربة في قضائي بدرة والحي، حيث توصل البحث إن المقومات الجغر افية قد أدت دور اً واضحاً في زيادة

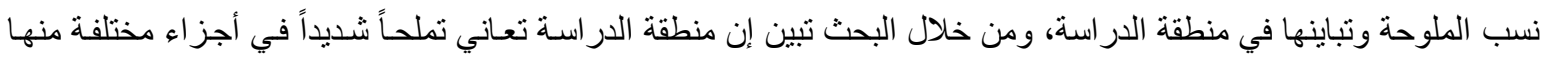

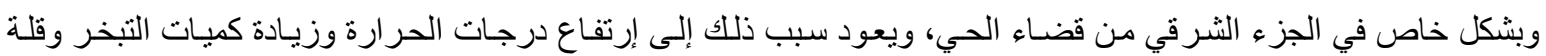
أنحدار السطح، فضلاً عن دور العو امل البشرية و المنمثلة بسوء إدارة الإنسان للأرض واليناه و أثر ذلك في تقلص المساحات

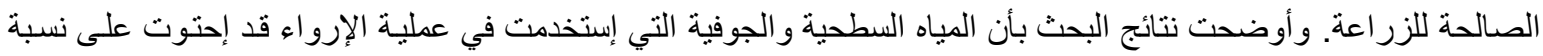
من الأملاح، و هذا ما تم إثباته بعد الاطلاع على نتائج نحاليل ملوحة المياه للنماذج المأخوذة من ضمن المنطقة، إذ تجاوزت نسبة التهاه

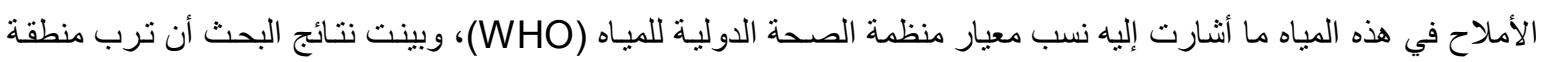

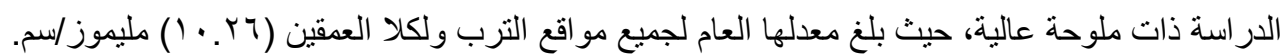

Abstract:

The Research Soil Salinization In Badrah And Al-Hai District, Where Up Search For Geographical Constituents Has Resulted A Clear Role In The Increase In Salts, And Contrast Ratios In The Study Area, Through Research It Shows That The Study Area Suffered Severe Salinity In Different Parts Of Them Particularly In The Eastern Part Of The Al-Hai District, Is Because Of To Rising Temperatures And Increased Amounts Of Evaporation And Lack Of Slope Surface, As Well As The Role Of Human Factors And Human III-Management Of Land, Water And Impact On Diminished Arable Area.

And The Results Showed That The Surface Water And Groundwater, Which Were Used In The Irrigation Process That Already Contains A Percentage Of Salts, This Was Confirmed After Seeing The Results Of The Salinity Of The Water Models Of Taken From Within The Region Analysis, If The Proportion Of Salts In The Water Exceeded Ratios As Noted By International Health Organization Standard For Water (Who), It Also States That The Study Area Soils Are Highly Salinity, Whose Total Range For All The Locations Both Depths Is (10.26) Mlimosz/Cm.

\section{الاقدهة:}

تعد ملوحة التربـة أحدى المشـاكل الرئيسة في المناطق الجافة وشبه الجافة وفي واقع بلدنا ولاسيما في المناطق الوسطى و الجنوبية فقد أصبحت مشكلة الملوحة من المشـاكل الأساسية التي تواجها القطاع الزر اعي العر اقي و أن معظم أر اضـي وسط العر اق وجنوبـه تخضـع إلى درجات مختلفة من التملح. أن مشكلة التملح برزت كمشكلة حقيقية في منتصف القرن الماضي، إذ أن الري المستمر للأغر اض الزر اعية وإخـال قنوات الري وسيلة للتوسع الزر اعي أدى إلى تملح الكثير من الأراضـي فضـلا عن عدم التوازن بين الري والبزل، وبالتـالي مشـاكل في التصـريف وكذلك ضـف البزل الطبيعسي بسبب انحدار الأرض القليل جداً فضـلاً عن مستوى الماء الجوفي الضحل وملوحته العالية، كما أن المناخ الجاف يميز المنطقة مـع أرتفاع معدلات التبخر

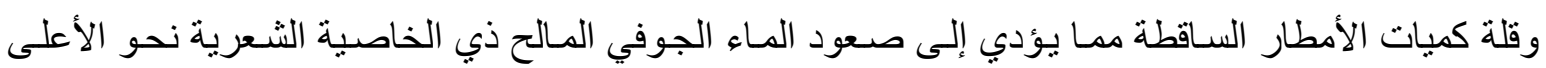


وتر اكم الأملاح على سطح التربة العلوي، فضلاً عن خواص تربة السهل الرسوبي التي تمتاز بكونها رواسب نهرية ناعمة النسجة ونفاذية واطئة و هذا ما يسبب صعوبة حركة الماء و الأملاح.

تذهب مشكلة البحث إلى الكثف عن التباين المكاني لقيم ملوحة التربـة في قضـائي بدرة و الحي ويمكن

صياغة هذه المشكلة بالتساؤلات الآتية: هل توجد تباينات مكانية لقيم الملوحة في تربة قضائي بدرة و الحي؟

يمكن صبياغة فرضية البحث بالعبارة التاليـة: إن قيم الملوحسة تتباين مكانياً في تربـة قضـائي بدرة

والحي لتباين العوامل الجغر افية المؤثرة في نشوءها.

ثالثًا: هدود البمث:

اـ حدود مكانية: تعد منطقة الدراسـة جزءاً من السهل الرسوبي وتشمل قضـائي بدرة والحي في محافظة و واسط الو اقعة ضمن المنطقة الوسطى من العر اق، إذ تتمثل بـالموقع الفلكي لقضـاء بدرة الذي يقع بين دائرتي

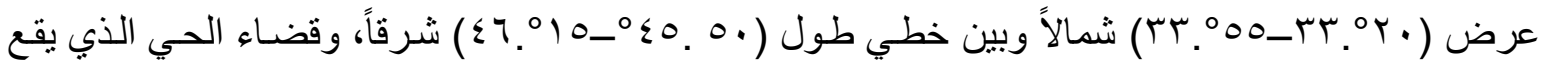

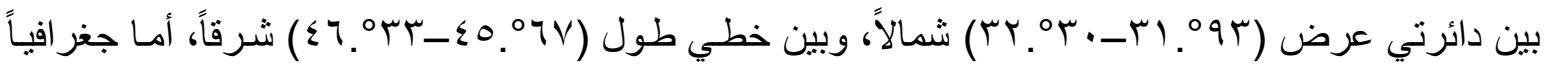
فبالنسبة لقضاء بدرة الذي يقع في الجزء الثمالي الثرقي لمحافظة و اسط تحدهُ محافظة ديالى من الثمال ومن الجنوب قضـاء الكوت ومـن الغرب قضـاء العزيزيـة ومن الثـرق جمهوريـة إيران الإسـامية، بنظر خريطـة ( (1)، أما بالنسبة لقضاء الحي الواقع جنوب المحافظة فيحدهُ من الشمال قضـاء الكوت مركز محافظة واسط ومن الجنوب محافظـة ذي قـار ومـن الجنوب الغربـي محافظـة القادسية ومـن الغرب ناحيـة الأحرار التابعـة لمركز قضاء النعمانية، ويحد القضاء من الثـرق ناحيـة واسط ضمن قضـاء الكوت. و وتتكون منطقة الدراسة

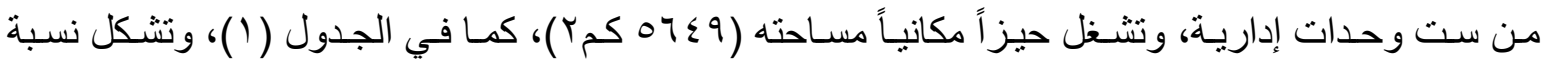

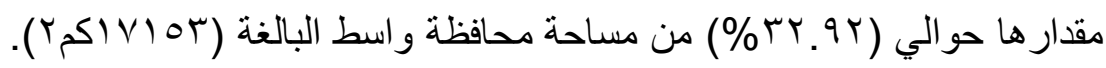

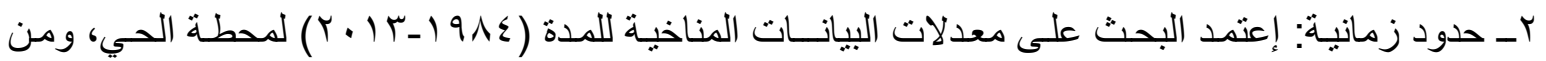

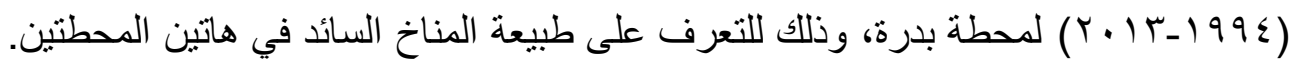

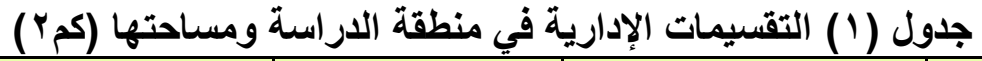

\begin{tabular}{|c|c|c|c|}
\hline نسبة المساحة من المحافظة & مساحة (كر r) & الوحدة الإدارية & أسم القضاء \\
\hline$\% v . \cdot v$ & $|Y| \varepsilon$ & مركز قضاء بلرة & \multirow{3}{*}{ قضاء بدرة } \\
\hline$\% 1 \cdot . \wedge r$ & 1104 & ناحية جصان & \\
\hline$\% \mu . r \wedge$ & $0 \wedge$. & ناحية زرباطية & \\
\hline$\%$ \% I.YV & m90. & \multicolumn{2}{|c|}{ مجموع قضاء بلرة } \\
\hline$\%$ \%.74 & 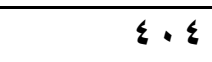 & مركز قضاء الحي & \multirow{3}{*}{ قضاء الحي } \\
\hline$\% \overline{\% Y r}$ & 1.10 & ناحية الموفقية & \\
\hline$\%$ \%.qV & 01. & ناحية البشائر & \\
\hline$\% 11.70$ & 1999 & \multicolumn{2}{|c|}{ مجموع قضاء الحي } \\
\hline$\%$ \%r.qr & $07 \leqslant 9$ & & المجموع \\
\hline
\end{tabular}

المصدر: جمهورية العراق، وزارة التخطيط والتعاون الإنمائي، الجهاز المركزي للإحصاء وتكنولوجيا

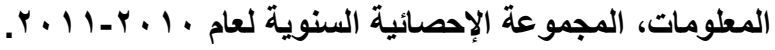




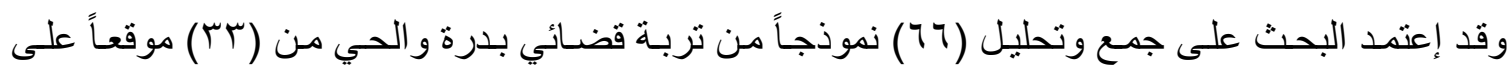

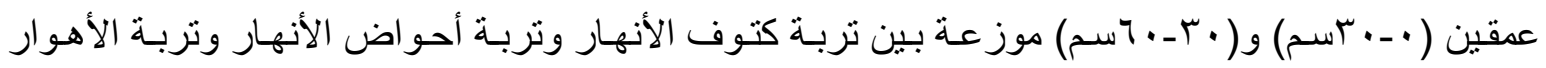
وتربـة المستنقعات وتربـة الكثبـان الرملية وتربـة المراوح الغرينية، وقد توزعت هذه العينـات على الوحدات الإداريـة في قضـاء بـدرة بواقع (ع ) عينـة لمركز قضـاء بـدرة و(V) عينـة لناحيـة جصـان و(ع ع) عينـة لناحيـة زرباطية، فيما توزعت على الوحدات الإدارية في قضاء الحي بواقع (؟) عينة لمركز قضاء الحي و(^) عينـة لناحية الموفقية و(ع ) عينة لناحية البشائر.

\section{رابعاً: هدف الدراسة :}

يهـدف البحـث إلـى الكثـف عن التباينـات المكانيـة لقيم الملوحـة في تربـة قضـائي بـدرة والحي وتحليـل المتغير ات الطبيعية والبشرية المؤثرة في هذا التباين. خامساً: منهجية البحث: إن ومن أجل وصول البحث إلى غايته الموسومة هذه فقد أتبع المنهج الوصفي والتحليلي مستعيناً بالأسلوب الكمي وتحليل نتائجه بالإعتماد على العديد من عينات الترب موز عة على عموم منطقة الدر اسـة وتوزيعها في

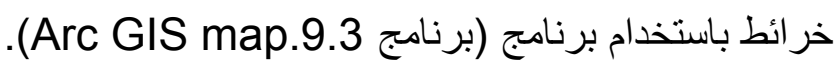

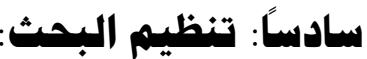

يتكون البحث من خلاصة ومقدمة وثلاثة مباحث، تناول المبحث الأول الإطـار النظري، أمـا المبحث الثناني فقد تتاول در اسة مفهوم ملوحة التربة والعو امل المؤثرة في أنتشـار ها في منطقة الدر اسـة، أمسا المبحث الثالث فقد أختص بدر اسة التباين المكاني لمعدلات ملوحة التربة في منطقة الدر اسـة، ثم توصل البحث إلى مجموعة من الاستتتاجات و التوصيات التي تخدم منطقة الدراسة. خريطة ( ) موقع منطقة الدر اسة بالنسبة لمحافظة واسط

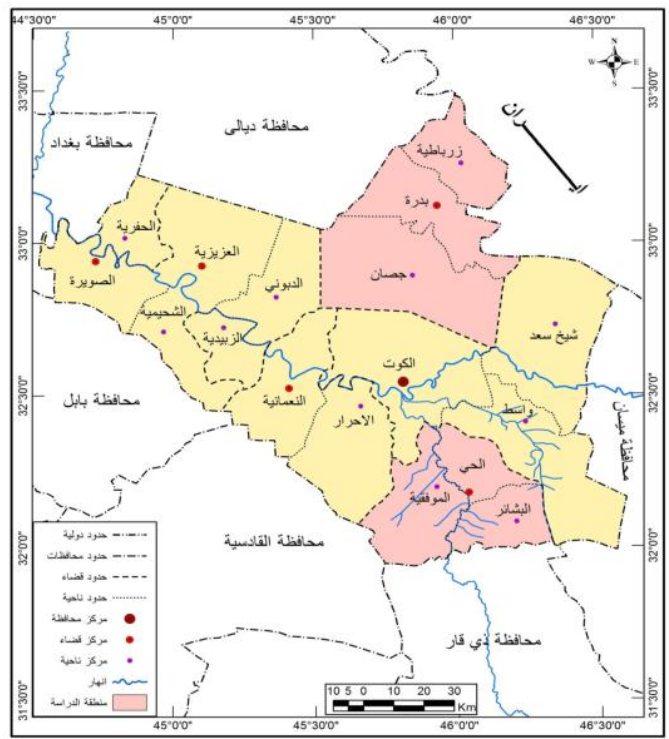

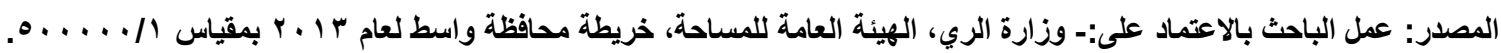




\section{أولاً: مفهوم ملوهة التربة:}

بطلق عادة تعبير الأر اضي المتأثرة بـالأملاح على الترب التي تحتوي على تركيز عالي من الأملاح التي تتسبب في رداءة الصفات الفيزيائية لها حيث يكون إرتفاع تركيز الأملاح الذائبة فيها لدرجـة أنها تتعارض وتؤثر في نمو النباتات بصورة عامة، وعادة يقاس تركيز تلك الأمـلاح الذائبة على أسـاس التوصيل التوصيل الكهربائي لمستخلص العجينة المشبعة(')، وتتكون الترب المتأثرة بالأملاح في المناطق التي يكون فيها تر اكم الأملاح أكبر من إزالتها حيث إن حركة الأمـلاح في القتـرة الأرضية التي تحدث فيها التجويـة يظهر خـلال محلول التربـة بدرجـة رئيسية(r)، ونتيجـة لتبخر المـاء الأرضـي من سطح التربـة الصـاعد بو اسطة الخاصية

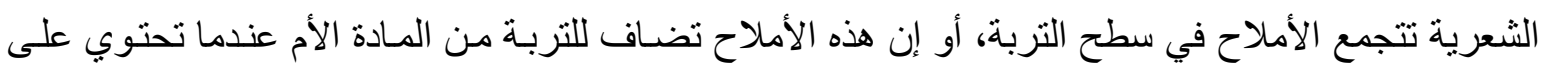
كميـات مـن الأمـلاح (َّوذكر الخبير الهولندي (Buring) في دراسـته عن أحسوال التربـة في العـراق عـام ( • (197) إن التملح هو من عمليات تكوين التربة الأساسية في المناطق الجافة وشبه الجافة و لاسيما ذات المـاء الأرضي المرتفع و أثـار بـأن التملح في هذه الترب هو نتيجـة تجمع المـاء الأرضـي في التربـة وقلة كميـات الأمطـار السـاقطة إذ تتجمع الأمـلاح الذائبة في التربـة والمنطقة الجذريـة بسبب إرتفاعهـا مـع المساء الأرضـي المتبخر من السطح، وأوضتح إن هذه الترب تتميز بوجود أفق ملحي يمتد لأكثر من (0 (1) سنتمتر ويحتوي على الأقل (r\%) من الأملاح (ఓ). وتتميز معظم أر اضـي وسط العراق وجنوبـه بتر اكم الأمـلاح الذائبة في التربـة مثنل كلوريدات وكبريتـات الصوديوم و الكالسيوم و المغنيسيوم(0)، حيث تكون كمية الأمطار غير كافية لغسل الكميات الزائدة من الأملاح المذابة في التربة، هذا فضـلاً عن الري المفرطوسو واء التصريف للتربـة، وإرتفاع درجات الحر ارة و التبخر

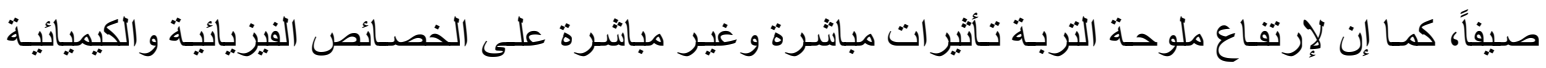
و البايلوجية للتربة ومن ثم النبات حيث يكون تركيب التربة غير جيد مع تشتت مجاميعها البنائية وتكون بشكل متباعدة عن بعضها البعض مع قلة واضحة في نسبة المسامات الهوائية، وهذا له تأثنير في خفض نفاذيـة التربـة للماء مع أنخفاض نسبة الأحياء المسؤولة عن تحلل المواد النباتية و الحيو انية مما ينعكس أثره على نسبة المـادة العضوية المتحللة والمضافة إلى التربة(؟)، وتصنف الترب بحسب الملوحة كما يوضح جدول (Y) (ب). جدول (r) أصناف الترب بحسب درجة ملوحتها

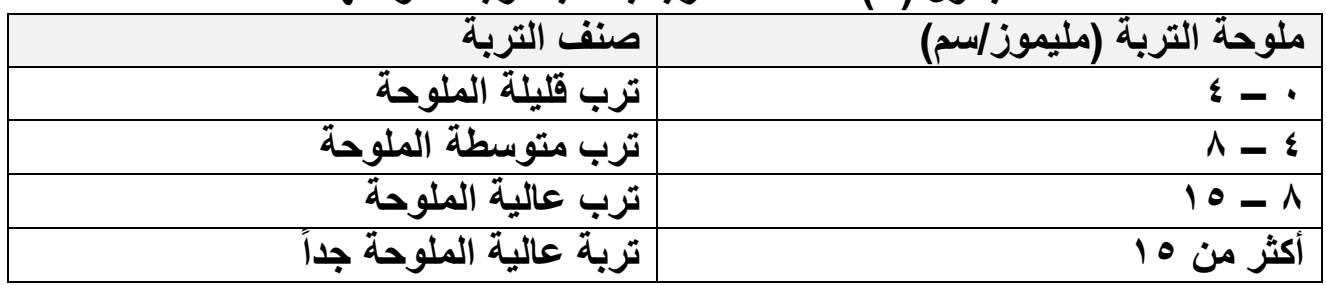

Source: FAO Unesco, Irrigation Drainage, Salinity , An international Source, Book London, Hutchin son, aelco, 1973, P75.

وقد إعتمد مختبر الملوحة في الولايات المتحدة الأمريكية عام ( 90 ( ) ثلاث مؤشرات رئيسـة في توصيف وتصنيف التـرب المتأثرة بـالأملاح وهي ملوحسة التربـة (Ec)، درجـة تفاعل التربـة (ph)، والنسبة المئويـة للصوديوم المتبادل (ESP)، والاعتبار ات التي أخذت بنظر الاعتبار عند اختبار المؤشر ات الثناث تكمن في

مدى تأثثير ها في صفات التربة ونمو النبات، كما في الجدول (r). 
جدول (r) تصنيف الترب المتأثرة بالملوحة وفقاً لمعيار مختبر الملوحة الأمريكي (U.D.A)

\begin{tabular}{|c|c|c|c|}
\hline المتبادل (ESPـــة المئويـة للصــوديوم & تفاعل التربة (ph) & (مليموز/سم) & لتربة \\
\hline اقل من إ\% & اقل من •.ر & اقل من ع & تربة غير ملحية \\
\hline اقل من 1 ا \% & اقل من •.ر & أكثر من ع & تربة مل \\
\hline أكثر من 1 \% & اقل من •. & أكثر من ع & يبة قلوية \\
\hline أكثر من 0 \% & أكثر من A.0 & اقل من ع & \\
\hline
\end{tabular}

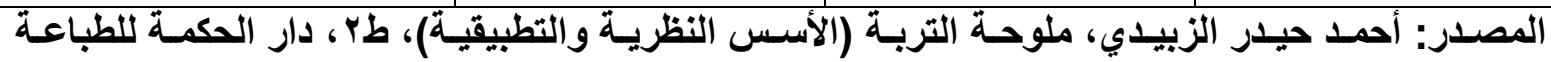

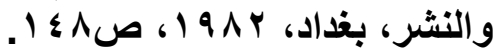

\section{ثانياً: العوامل الجغرافية المؤثرة في انتشار الأملام في ترب منطقة الدراسة:}

اــ العوامل الطبيعية: ترتبط ظـاهرة التملح و إرتفاع مستوى ملوحـة التربـة بعدد كبير من العوامل الطبيعيـة

المناخية و الطوبوغر افية و الهيدرولوجية خصوصاً في المناطق ذات المناخ الجاف وشبه الجاف وكما يأتي: أ - المناخ: يتصف مناخ منطقة الدر اسة بأنه إمتداد للمناخ الصحر اوي الذي يسود في وسط وجنوب العراق، إذ تقع ضمن المنطقة شبه المدارية وضمن المناخ المداري الصحر اوي (Bwh) حسب تصنيف كوبن للأقاليم المناخية في العراق(')، وتؤثر درجات الحرارة بشكل واضح في تفاقم مشكلة الملوحة وزيـادة مخاطر هـا، إذ يؤدي إرتفاع درجات الحرارة إلى زيادة قيم التبخر الذي بعكس تأثثره في زيادة نسبة الملوحسة في التربـة سواء عـن طريـق تبخـر الميـاه السطحية أو نتيجـة لإرتفـاع الميـاه الجوفيـة المالحـة بو اسطة الخاصية الثـعرية إلى

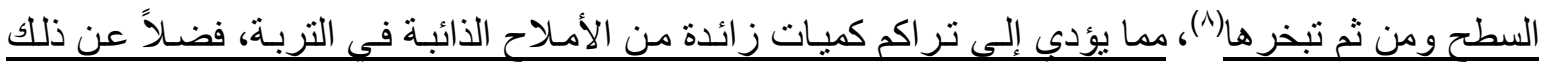

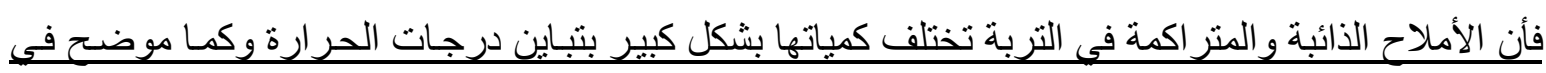
الجدولين (0، ؛)، إذ يتبين إن درجـات الحرارة العظمى خـلال أشـهر الصـيف (حزيـران، تمـوز، آب) بلغت

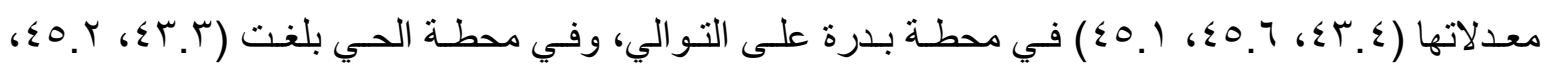

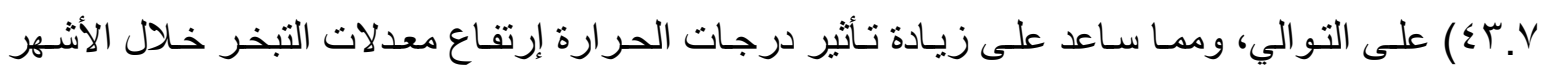

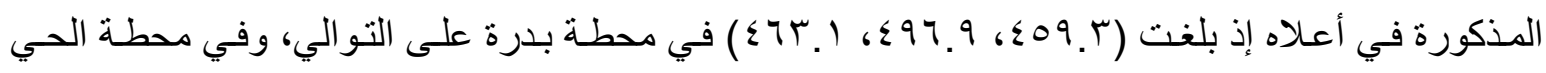

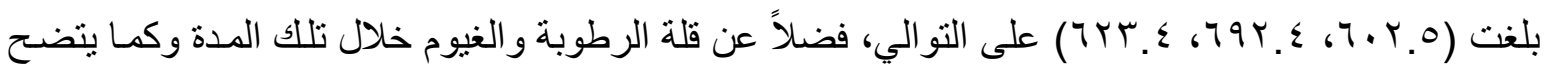
من الجدول المذكور. ومن العناصر المناخيـة التي سـاهمت في تفاقم مشكلة الملوحة في منطقة الدراسـة هو زيادة سرعة الرياح التي تؤدي إلى زيادة نسبة التبخر في التربة، لأن الرياح تعمل على إز احة الطبقة المشبعة ببخار الماء وتحل محلها طبقة جافـة ومن ثم تزداد معها الأمـلاح في التربـة ممـا تؤدي إلى زيادة المسـاحات

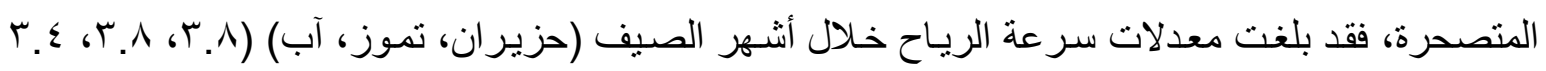

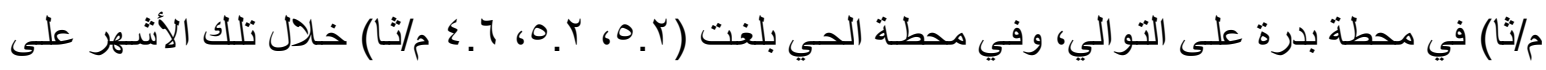
التو الي. كما إن قلة تساقط الأمطار من خلال معدلات التساقط لمنطقة الدر اسـة عمل على زيـادة نسبة الملوحـة وذللك لأنها لا تكفي لغسل التربة أو إرواء المحاصيل الزر اعية، إذ إن قلة التسـاقط في فصل الثتاء عمل على هلى الاعتماد مياه الري الأخرى لسد متطلبات النبات من المياه في كافة المناطق وهذه المياه تحوي على كميات متفاوتة من الأملاح بعضها عال مثل مياه الآبار و المبازل وكلما يزداد عدد الريات تزداد كمية الملوحة.

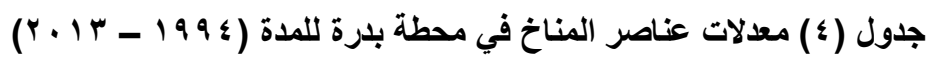




\begin{tabular}{|c|c|c|c|c|c|c|c|}
\hline معدل التبخر & 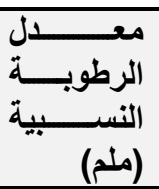 & 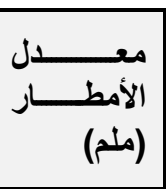 & 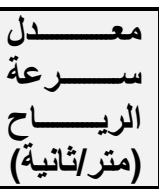 & 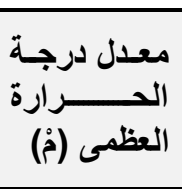 & 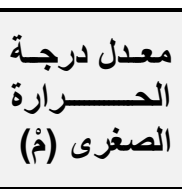 & 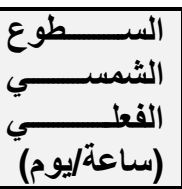 & اللمناصية \\
\hline 70.8 & $\overline{v i . r}$ & $\$ 1.7$ & $Y . \xi$ & 19.4 & 7.1 & 0.9 & كפץ \\
\hline $9 V_{.0}$ & 09.9 & $r \leqslant .0$ & Y.V & 19.8 & V. 9 & 1.9 & شباط \\
\hline 111.0 & $\leqslant 7.9$ & Y Y.\& & r.1 & $r \leqslant . V$ & 11.1 & $V_{. \wedge}$ & آذار \\
\hline$r \leqslant r . \wedge$ & $\varepsilon \cdot .1$ & $1 \leqslant . r$ & r.Y & rI.r & $1 V .0$ & $\Lambda . Y$ & نيسان \\
\hline$r \leqslant \Lambda_{.} \varepsilon$ & Y^.q & TY.Y & $r$ & $r \wedge .1$ & YY.q & 9.4 & مايس \\
\hline$\leqslant 09.4$ & Y. 1.7 & 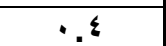 & $r . \wedge$ & $\varepsilon \Psi . \xi$ & Yฯ.० & 11.9 & حزيران \\
\hline$\{99.9$ & $\overline{r \cdot . r}$ & - & $\overline{r . \Lambda}$ & $\$ 0.7$ & YV.r & $11 . \varepsilon$ & تموز \\
\hline$\leq 4 \pi .1$ & $r \cdot . q$ & - & r. & $\leqslant 0.1$ & YV.A & 11.8 & آب \\
\hline$r 01.7$ & ro.r & 1.9 & Y.9 & $\varepsilon 1 . r$ & rr.o & $1 \cdot . \varepsilon$ & أيلول \\
\hline YTY.Y & $r \varepsilon . r$ & 17.1 & Y.r & $r \varepsilon_{. \wedge}$ & 19.5 & 1.0 & ت \\
\hline 111.9 & $04 . \xi$ & rq & Y.1 & $Y \leqslant . q$ & $11 . \varepsilon$ & $V_{.}$. & ت \\
\hline$v \cdot . \wedge$ & TV.1 & TY.Y & r & $1 \Lambda . Y$ & $V . Y$ & 0.9 & كأ 1 \\
\hline Y4..Y & $\$ 1$. & $r \cdot$. & Y.A & 41.9 & IV. $\varepsilon$ & $\Lambda . V$ & المعدل السنو \\
\hline
\end{tabular}

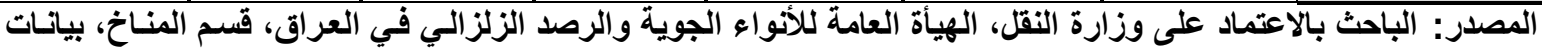

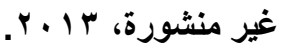

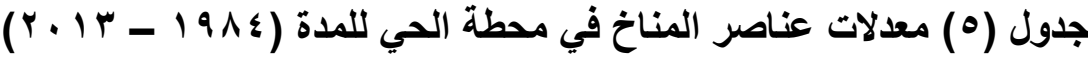

\begin{tabular}{|c|c|c|c|c|c|c|c|}
\hline معدل التبخر & الرطوبة & $\begin{array}{l}\text { (المطار } \\
\text { (ملث) }\end{array}$ & مترعة مترلة الرياحة) & معدل درجة العظمى (مْ) & 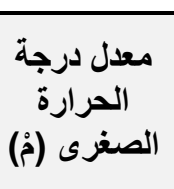 & (الشمسطوع الفعلي & \\
\hline 99.7 & 79.9 & $r \Lambda_{.} \wedge$ & $\overline{r . r}$ & $T V . Y$ & 7. & 7.0 & كצ' \\
\hline IY . & T1.r & 19.1 & $r . \wedge$ & $r \cdot .1$ & ก.V & $V . \varepsilon$ & شباط \\
\hline YY..Y & 04.9 & $19 . r$ & $r . \wedge$ & ro.1 & TY.V & $\bar{V} . \wedge$ & آذار \\
\hline$r \cdot r . r$ & $\varepsilon 0 . Y$ & $1 \% . \Lambda$ & $r .9$ & $\Gamma . \wedge$ & $11 . \varepsilon$ & $\Lambda . r$ & نيسان \\
\hline$\varepsilon \leqslant r . V$ & $r \mu .1$ & 0.1 & \&.1 & $r \Lambda_{.0}$ & $r \leqslant . r$ & $9 . V$ & مايس \\
\hline T.r. & Yo.r & - & $0 . Y$ & $\varepsilon r . r$ & $r V_{. \wedge}$ & 11.0 & حزيران \\
\hline 79Y.\& & $r \leq .1$ & - & 0.1 & $\$ 0 . Y$ & r9.0 & 11.0 & تموز \\
\hline Tr.\&. & $r \leq . q$ & - & $\varepsilon .7$ & $\varepsilon \Psi . V$ & rq.1 & $11 . r$ & آب \\
\hline$\varepsilon \vee 9.0$ & $r \Lambda .{ }^{\circ}$ & 9.7 & \&.1 & $\$ 1.9$ & ro.1 & $1 \cdot .1$ & أيلول \\
\hline$m 11 . v$ & $r \Lambda . \Lambda$ & $\varepsilon .0$ & r. & $r 0.0$ & $r \cdot . r$ & $\Lambda .7$ & ت \\
\hline $17 \% . V$ & 07.0 & rT.r & T.६ & YO.V & 14.1 & $V_{.} \varepsilon$ & ت \\
\hline 118.7 & $7 V .1$ & YI.V & r.1 & 19.5 & $\Lambda .7$ & 8.8 & ك5 \\
\hline$r \leqslant 9 . r$ & «.. & $1 \xi . V$ & r.9 & YY.Y & 11.7 & $\Lambda . \Lambda$ & المعدل السنوي \\
\hline
\end{tabular}

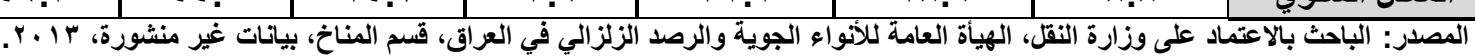

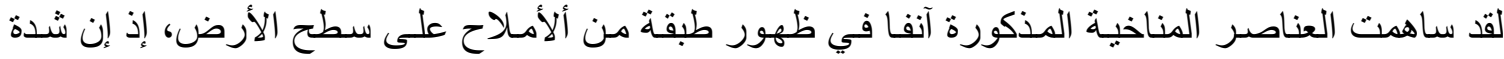
التبخر تؤدي إلى زيادة ترسب الأملاح في الترب المرويـة والغدقة، وكذلك نؤدي إلى زيادة نشـاط الخاصية الثـعرية (Capillary Action) في التربـة، وهذا مـا تمت مشـاهدته في الدراسـة الميدانية في أغلب مو اقع اقع منطقة الدر اسة، إذ أدت شدة التبخر إلى ظهور طبقة ملحية بيضـاء على سطح التربـة لاسبما في غرب ناحيـة الموفقية، ينظر صورة ( (). صورة (1) جانب من ترب أحواض الأنهار المتملحة غرب ناحية الموفقية

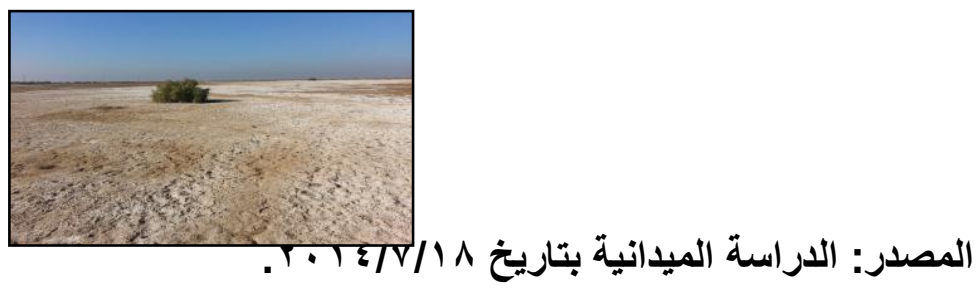


ب - البنية والتركيب الجيولوجي:

تعد منطقة الدر اسة من الناحية الجيولوجيـة جزءاً من سـهل وادي الر افدين الذي نتج عن الحركات البانية للجبال التي بلغت أوجها قبل حو الي مليوني سنة ماضية وأستمرت حتى يومنا هذا ولكن بثدة أقل، وقد تسببت هذه النشاطات التكتونية (البنيوية) الحديثة في نشوء العديد من المظاهر الجيومورفولوجيـة الحالية في مناطق السهل الرسوبي والمتمثلة بظهور عدد من المرتفعات الحالية المتتاثرة في المنطقة والمنخفضـات كـ(الأهوار) علاوة على إنقطاع وجفاف وتغيير مجاري الأنهار (9.) و أثنتملت منطقة الدراسـة على رواسب البلايستوسين و العصر الحديث ومن الرسوبيات النهربة الحديثة من الرمال و الطين الغريني، إذ تمتزج مـع بعضهها البعض

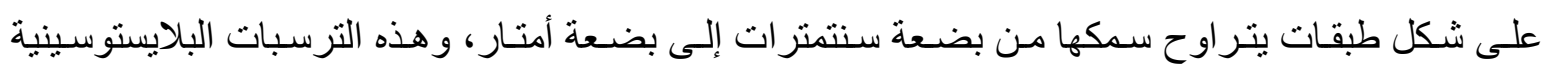

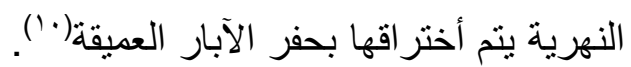
أما ترسبات المراوح الغرينية فتغطي قثرة جبسية تكون أمـا متماسكة أو على هيأة مسحوق جبسي يصل سمكها إلى (rمثر)، وتكون ترسبات الانسياب السطحي سهل واسع بمتد بين المراوح الغرينية ونهر دجلة، سمك هذه الترسبات يتر اوح مـابين بضعة أمتار إلى (0 (متر) عند حدود التمـاس مـع المراوح الغرينية في

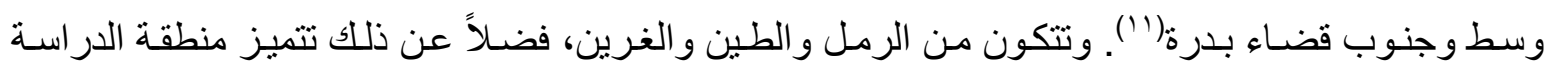
بوجود ترسبات المنخفضات الضحلة وتحتوي هذه الترسبات على كمية عالية من الأمـلاح الناتجة عن تبخر المياه في فصل الصيف، لذلك تكون جافة لمدد طويلة، وهنـاك بعض المنخفضـات الصـيرة لاسيما منطقة

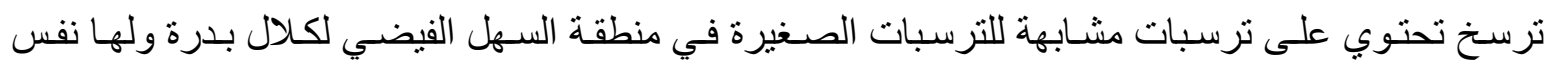
التأثير على مقدار التصريف السطحي. ج- - السطح: تتألف منطقة الدر اسة من وحدتين طبيعيتين همـا منطقة المراوح الغرينيـة ومنطقة السهول الفيضية، وكما يتضح من الخريطة (r)، ولمنطقة المراوح الغرينية أهمية واضحة في نقل الرواسب على شكل فتات صخري وطيني ورملي وغريني لترسبها أسفل تلك المنحدرات مكونـة منها تربـة على شكل مر اوح طينية وحصوية،

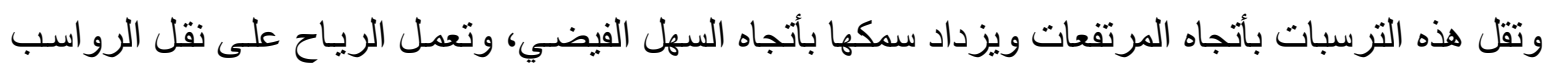
الناعمة وبقاء الرواسب الخشنة على السطح بشكل بـارز (ז')، وتتميز هذه المنطقة بقلة الغطاء النباتي نتيجة للظروف المناخيـة الجافـة. أمـا منطقة السـهول الفيضية فتغطي هذه المنطقة معظم مسـاحة منطقة الدر اسـة، وتظهر على جانبي نهر الغر اف ونهر كلال بدرة، وتنشأ مثل هذه السهول على جانبي المجرى النهري نتيجة إلقاء النهر ما يحمله من رواسب على جانبيه خلال مدة الفيضانات حين يطغى النهر على جانبيه ويتسع مجر اه وتنخفض سرعته فيطرح ما يحمله من عو الق ورواسب على المناطق المحاذية لمجر اهوتكر ار هذه العملية يولد سهو لاً إرسابية مغطاة بفرشاة غرينية أو طينية سميكة(r'). 


\section{خريطة (ץ) مظاهر السطح في منطقة الاراسة}
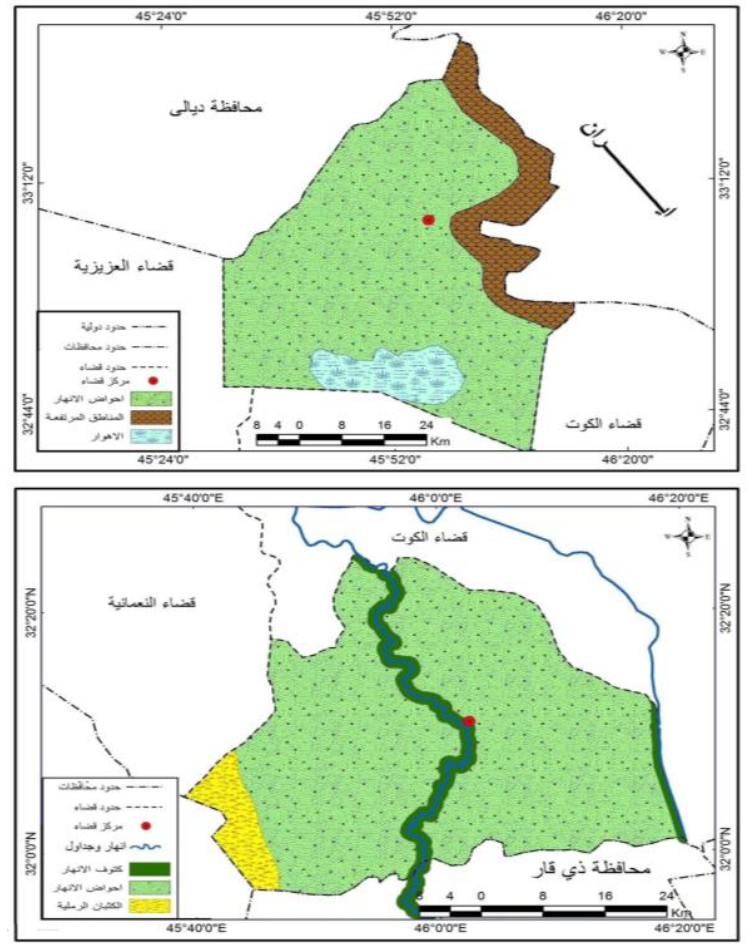

المصدر: الباحث بالاعتماد على وزارة التخطيط، هيئة التخطيط الإقليمي، الواقع التموي لمحافظة واسط، ... r، صبr

يبدأ السهل الفيضي لنهر كلال بدرة بالانحدار العام من الثرق نحو الغرب يبدأ بـالقرب من ناحية زرباطية

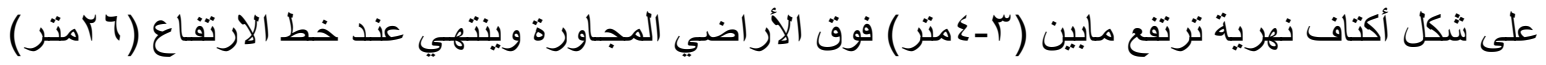
من قضاء بدرة حتى يصل إلى أدنى انخفاض لله عند منخفض هور الثويجة عند خط الارتفاع (r (rمتر)،

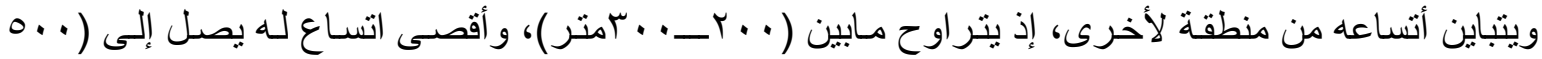
متـر) على مقربـة مـن مركـز مدينـة بـدرة، ويتكـون مـن رواسـب نهريـة متنو عـة مـن (الحصـى و الرمـل و الطين)(؛ ()، وقد ساعد هذا الانحدار على تصريف المياه القادمة من الجهات الثـرقية بهذا الاتجـاه و لاسيما إن تللك المياه تحمل معها الأملاح الذائبة بعد مرور هـا على تكوينـات جيولوجية حاويـة على تر اكيز ملحية، حيث تتجمع تللك المياه في منخفض الثويجة وأثناء فصل الصيف يتبخر جزء من تلك المياه مخلفة ور ائها الأملاح المنرسبة(10) أما السهل الفيضي لنهر الغراف فينحدر بصورة عامة من الثمال نحو الجنوب والجنوب الغربي، يبدأ من خط الارتفاع (1 (متر) عن مستوى سطح البحر الذي يمثل جنوب قضاء الكوت ويتدرج في الأنففاض باتجاه

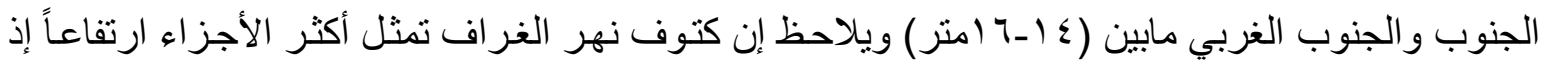

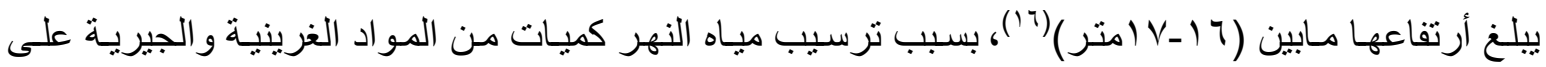
ضفتيه في حين لاتحصل المناطق البعيدة والمعروفة بأحو اض الأنهار سوى كميات أقل من تللك المواد و التي غالباً ما تتكون من ذرات ناعمة تمتاز بصغر حجمها مقارنة مع مناطق كتوف الأنهار ، وقد أدى هذا الانحدار البسيط إلى تر اكم المياه الزائدة في منـاطق أحواض الأنهار وعدم تصدريفها ممـا يؤدي إلى تبخر هـا و إنتشـار

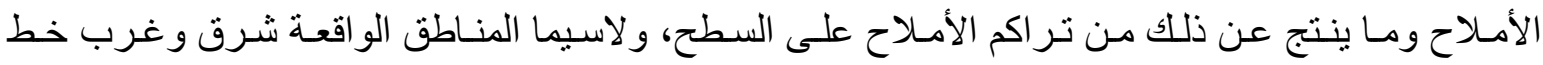
الارتفاع (ع (متر) الذي يعد أكثر مناطق الدراسة تركز للملوحة. 


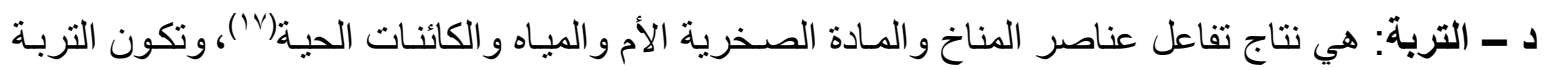
أمسا أصلية أي تربـة تكونت من نفس طبقة الصـور التـي توجد تحتهـا، وأمـا أن تكون تربـة منقولـة أب إنها تكونت في مناطق بعيدة عن الصخور التي إثتقت منهاو انتقلت بواسطة عو امل النقل كالمـاءو الهو اءو وترسبت في مناطق أخرى. ويمكن تصنيف تربة منطقة الدراسة إلى الأنواع الآتية وبحسب ما تظهره خريطة (؟r).

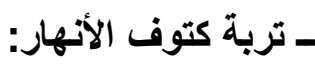
تنــل هذه التـرب النطاقـات المرتفعـة الو اقعـة على ضـفاف الأنهار وتعتبر مـن أخصب أنواع الترب في

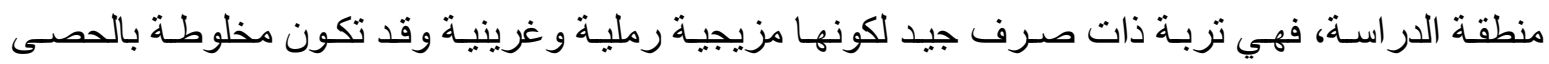
وساعدت وفرة المياه في إستغلالها في الزراعة، نظهر هذه التربـة على شكل أشرطة ضيقة محاذيـة لمجاري الأنهار يتموج سطحها قليلاً، أو كثير اً بحسب موقعها من الأنهار (^')، وقد بنيت من الرواسب الحديثة التكوين

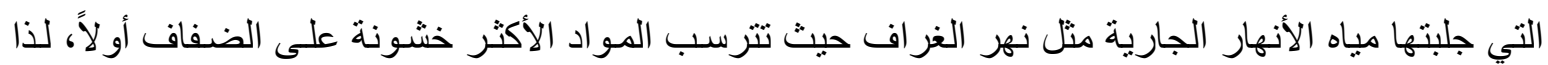
فهي متجانسـة لإحتو ائها على نسبة عاليـة من الجير و الطمئ(19)، و عمق اليـاه فيها بعيد عن السطح وهي تحتوي على العناصر الكيمياويـة والمعدنية وتمتاز بقلة أملاحها، وتتو اجد في ناحية الموفقية ومركز قضــاء الحي و هي ملائمة لزر اعة كافة المحاصيل الزر اعية. خريطة (r) أنواع الترب في منطقة الدراسة

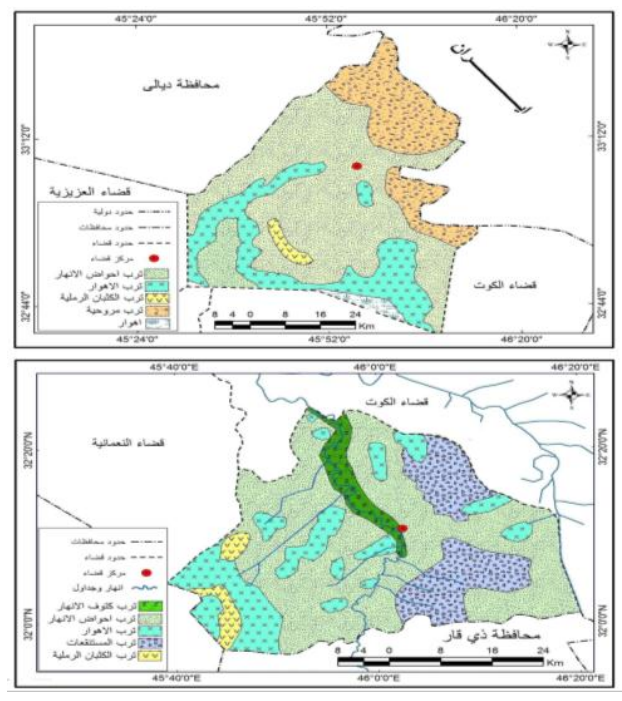

\section{ـ تربة أحواض الأنهار : مت}

تقع هذهِ الترب في المناطق التي تلي مناطق تربة كتوف الأنهار من السـل الرسوبي، وتكون ذات مستوى

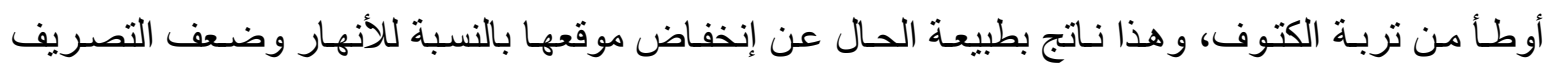
الخارجي، الأمر الذي يؤدي إلى بقاء المياه فوقها مدة طويلة دون نفاذها إلى الأسفل، كذلك إن عملية الغيض أو نفاذية الماء فيها تكون بطيئة و التصريف لها رديء مما يؤدي ذلك إلى ظهور عدد من البرك الصغيرة فوق بعض أجزائها التي ترتفع فيها درجـة الملوحة نسبياً، مما يؤدي إلى ظهور مشـاكل عدة كتغدق التربـة و إرتفـاع مناسيب الميـاه الأرضـية بسبب انخفاضـها النسبي عن مسـتوى مناسيب الميـاه في شبكة وجداول 


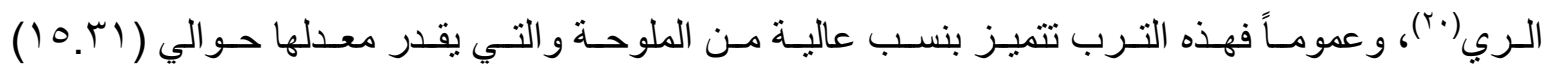
مليموز/سم، لذلك هي أكثر ملائمة لزر اعة محصول الثعير وبمساحات واسعة إذ يتحمل الملوحة العالية.

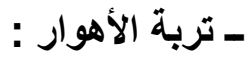

تتمثل هذه التربة فـي مناطق الأهو ار، وتنتشر في جهات متفرقة في منطقة الدراسـة إلا أن أوسع انتشـار اً لها هو في الجهات الجنوبيـة من قضـاء بـدرة المتمثلـة بناحية جصـان، وكذلك في الجهات الجنوبيـة الغربيـة من قضاء الحي المتمنلة بناحية الموفقية، وتُعدّ هذه التربة أخفض مناطق السهل الرسوبي، إذ يتراوح معدل ارتفاع السطح فيها بين (ع ( ـ Yrم) فوق مستوى سطح البحر، وبسبب إنخفاض مستو اها و إنبسـاطها أصبحت رديئة الصرف حيث يرتفع نتيجة لذلك مستوى الماء الأرضي فيها. و عليه ارتفعت فيها نسبة الأملاح مما جعلها غير صالحة للزر اعة كما مبين في صورة (r). صورة (Y) تجمع الأملاح في بعض ترب الأهو ار لمنطقة الدراسة

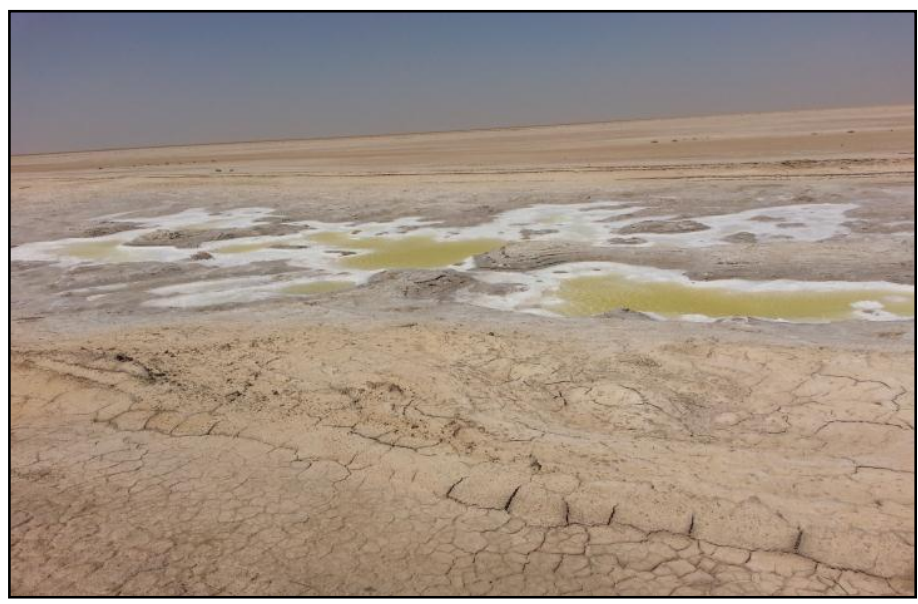

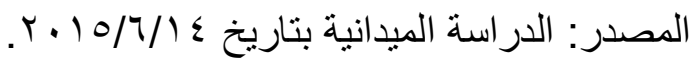

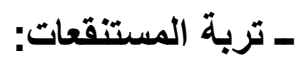

هـي ترب شـديدة الملوحـة لإمتلائهـا بالميـاه الدائميـة والموسـية التـي تنسـاب إليهـا مـن المنـاطق المرتفعـة

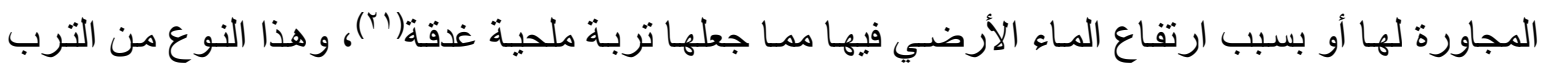

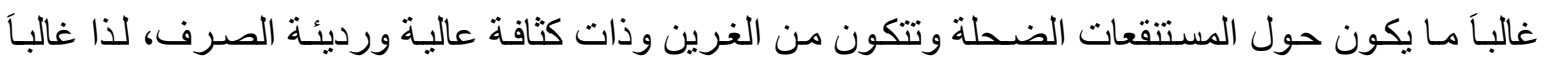
ماتكون مغمورة بالمياه، و هذا ما يمكن ملاحظته بشكل جلي في الترب الواقعة إلى الجنوب من نهر الغر اف، إذ تكون الأر اضي رديئة ومشبعة بالماء.

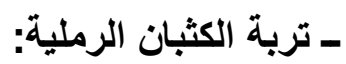
يؤلف هذا النوع من الترب حيزاً صغيرًا من منطقة الدراسـة ويسود في الجزء الغربي من ناحيـة الموفقيـة بمحاذاة قضاء عفلك بمحافظة القادسية، وفي مسـاحات صغيرة من وسط ناحية جصـان، وتتمثل بتجمعات من الرمال المتر اكمة المتكونة بفعل التعرية الريحية. وبما إن المناخ الحالي السائد في هذا الجزء من منطقة الدراسـة هو المنـاخ الجـاف الذي ترتفع فيـه درجـات الحرارة صيفاً فقد أشتد التبخر في هذه التربة وجعلها مفككة سهلة النقل بواسطة الرياح و إمكانية أنثارة مظاهر 


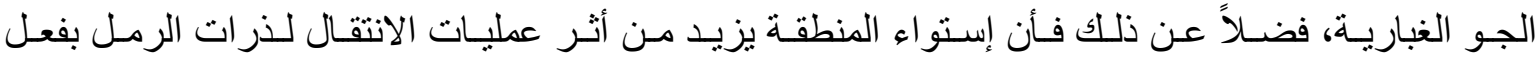

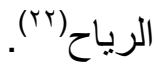
ـ تربة المراوح الغرينية: - ماتية تشغل هذه الترب مساحة تمتد بين الجناح الغربي لتلال حمرين والحافة الثرقية لمنخفض هور الثويجة، تكونت بفعل الرواسب المائية الموسمية للمجاري النهريـة (الكلالات) المنحدرة من المرتفعات الإيرانية تجاه هذا السهل والتي تتصرف إلى داخل المنطقة، مما أدى ذلك إلى تكوين الدلتاو ات المروحيةة(rr)، وتتصف هذه

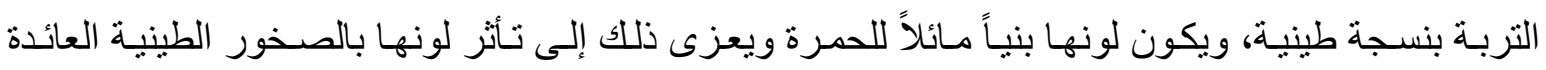
لتكوين انجانـة وتحتوي على تجمعـات من الكلس و الجبس، كمـا أنها متوسطة الملوحة وقليلة العمق بسبب

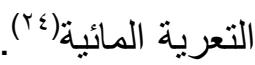

\section{هـ - النبات الطبيعي:}

يكون للنبات الطبيعي أثر كبير في زيـادة الأمـلاح الموجودة على سطح التربـة، إذ يسهم النبات في زيـادة الأملاح على سطح التربة من خلال نمو النباتات التي تمتص الماء بو اسطة الجذور تاركة الأمـاح عند الطبقة الجذرية. وتوجد هناك نباتات تعمل على مد جذور ها إلى أعماق مختلفة وتقوم بامتصاص الأملاح وتجميعا في جذور ها و عند تفسخها تترك كميات لابأس بها من الأمـاح متجمعـة على سطح التربـة كنبات الحمض الذي ينتشر في أجزاء متعددة من منطقة الدر اسـة. أمـا من جهة ايجابية يؤدي النبات الطبيعي كالحشـائش مثلاً إلى خفض شدة التبخر من سطح التربة، إذ تعمل جذورها على مد أمتصـاص المـاء خلال عملية النتح التي تؤدي إلى خفض تملح الطبقات العليا من التربة فتحسن من تركييه التربة وتزيد من نفاذيتها و لاسيما في الترب التي تتشط فيها الخاصية الثعرية مما يؤدي إلى التقليل من صسعد المـاء الجوفي إلى سطح التربـة وتقليل التبخر ومن ثم التملح. وتنتشر أنواع مختلفة من النباتات الطبيعية في منطقة الدر اسـة وهي تختلف بحسب أختلاف توزيع التربـة وتباينها، ونتيجـة لاستغلال التربـة في منطقة الدراسـة فقد انتشـرت أنواع عديدة مـن النباتـات الطبيعية و الأدغال فضلاً عن النباتات البرية الموجودة في المنطقة التي لم تتأثر بالاستغلال الزراعي. وتتكل النباتات الصحر اوية النبات السائد في منطقة الدراسة، التي هي من ضمن منطقة المنـاخ الصحر اوي الحار، إذ تضافرت أحوال المنطقة المناخية من تطرف في درجات الحرارة ونقص كبير في التجهيز المـائي في تكيف هذه النباتات لمو اجهة هذه الأحوال القاسية، فهناك النباتات التي تعيش في الترب الرملية التي تكيفت

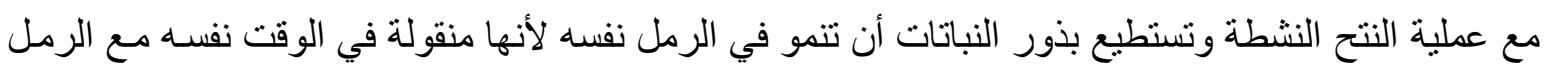

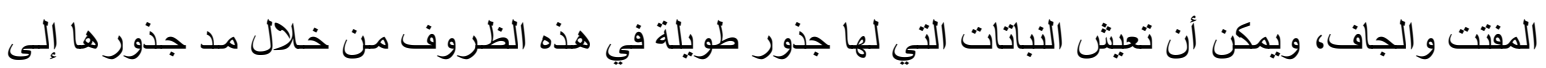
منـاطق الرطوبـة، ومن أمثلة النباتـات الصـحراوية في منطقة الدر اسـة هي الثـوك و العاقول و الاثل و الرمدث و الكبر، ينظر صورة (r). صورة (ب) نبات الطرفة المنتشر شمال شرق ناحية البشائر في منطقة الدراسة

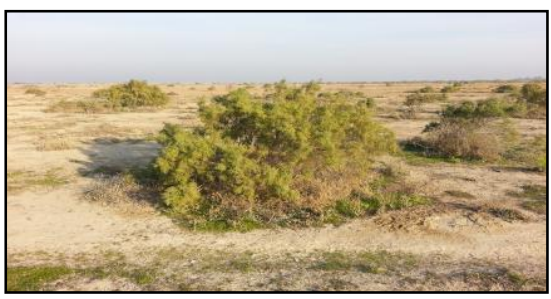


رابعاً - الموارد المائية:

تتمثل الموارد المائية في منطقة الدراسة بشكل رئيس في مصدرين أساسيين و هما:

1

يلاحظ من الخريطة (؟) إن المياه السطحية في منطقة الدر اسة تتمثل بما يأتي:أ ـ الأنهار دائمية الجريان:

نعني بها الأنهار التي يستمر جريان المساء فيها طيلة العـام، تتمثل هذهِ الأنهار في منطقة الدراسـة بنهر الغر اف الذي يتميز بجريانه المستمر في جميع فصول السنة ويستمد مياهه من نهر دجلة وكالآتي:

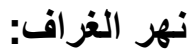
يمثل نهر الغراف أهم مصادر المياه بالنسبة لتربة قضاء الحي، ونهر الغراف فرع من نهر دجلة يأخذ مياهـه من مقدمة سدة الكوت أيمن نهر دجلة، ويقع في صدره نـاظم الغر اف ويستمر في جريانـه بأتجاه الجنوب الغربي من مقدم مدينة الكوت(ro)، وبما إن نهر الغر اف يأخذ مياهه من نهر دجلة، لذا فأن منطقة تغذيته تتمثل بحوض تغذية نهر دجلة، وتصل تصلاريف نهر الغر اف إلى أعلى مستوياتها خـلال المدة من شباط حتى نهايـة

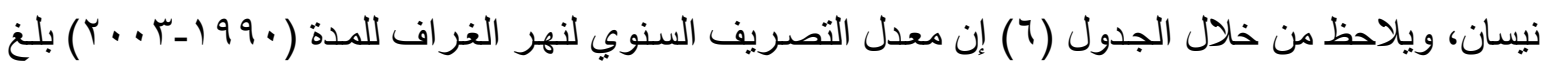

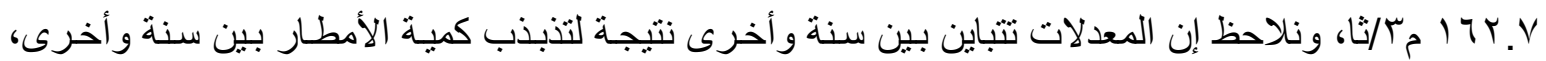

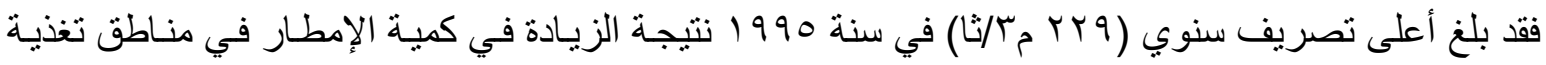

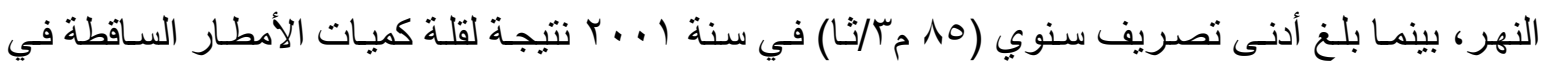
مناطق تغذية النهر. خريطة (ع) توزيع الموارد المائية السطحية في منطقة الدر اسة

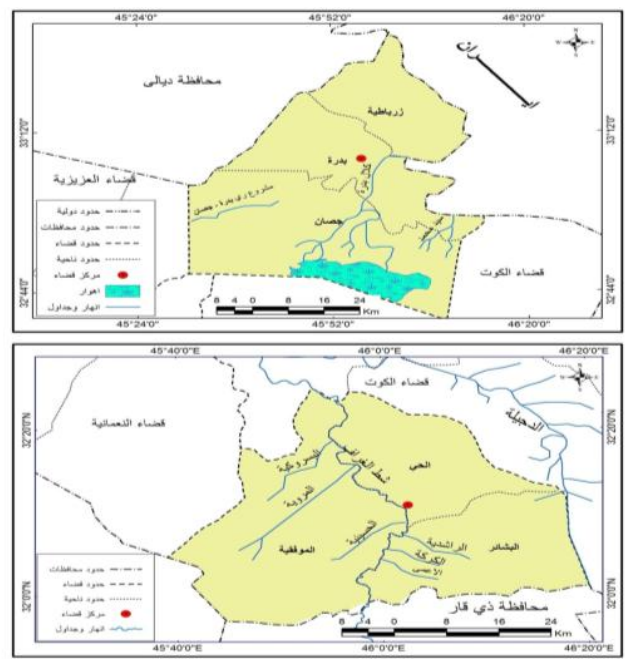

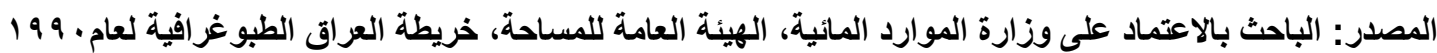

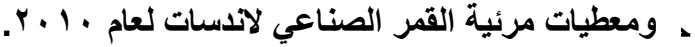

\begin{tabular}{|c|c|c|c|}
\hline نهر كلال ترساخ & نهر كلال بدرة & نهر الغر اف & السنو ات \\
\hline- & $1 . .1$ & $T \cdot V$ & 199. \\
\hline- & $11 . r$ & $|V|$ & 1991 \\
\hline- & $V .0$ & TYV & 1994 \\
\hline
\end{tabular}




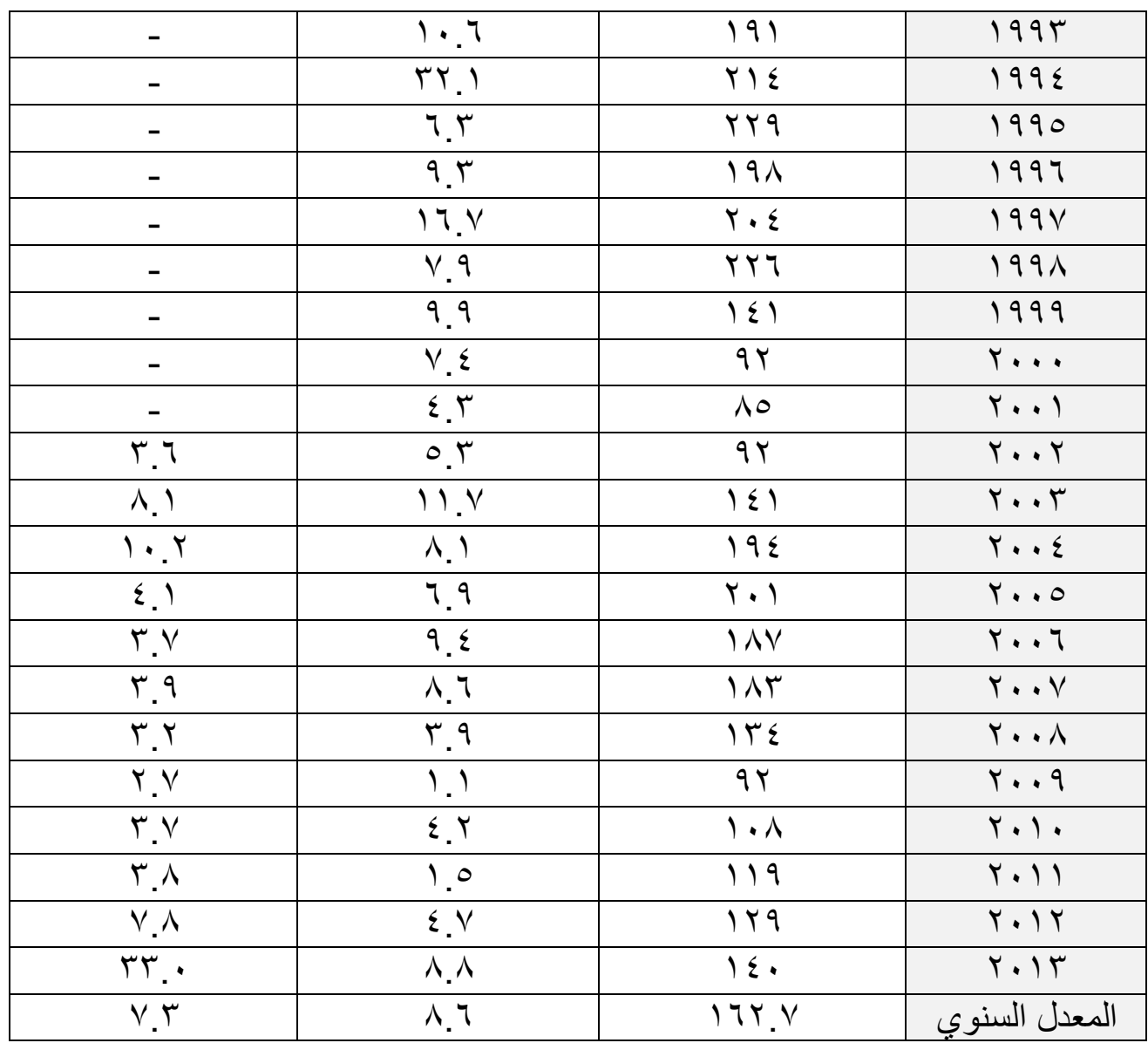

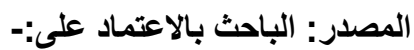

إ-ـاتوزارة الموارد المائية، المركز الوطني لإدارة الموارد المائية، قسم السيطرة والتحريات الهيدرولوجية

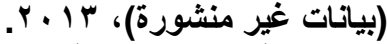

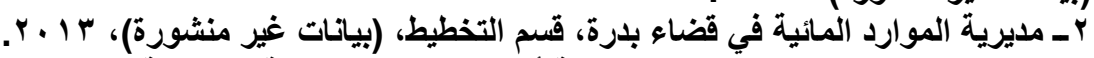

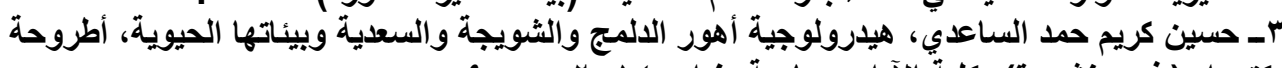

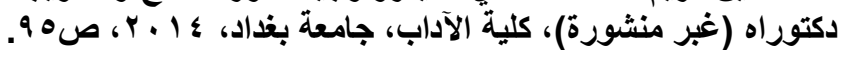

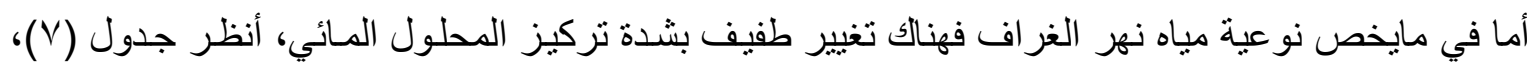
فبالنسبة إلى معدل قيمة الأسس الهيدروجيني (PH) فبلغت (P.V) في النماذج المدروسـة، أمسا درجة الأمـاح الكليـة الذائبـة (T.D.S) فبلغت (TV9 ملغم/لتر) )، أمـا بالنسبة لمعدل قيم التوصيل الكهربـائي (E.C) فبلغ

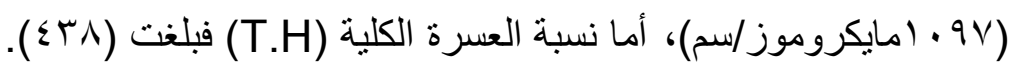

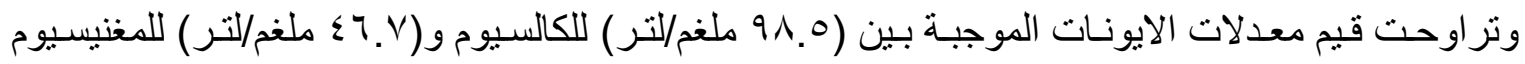

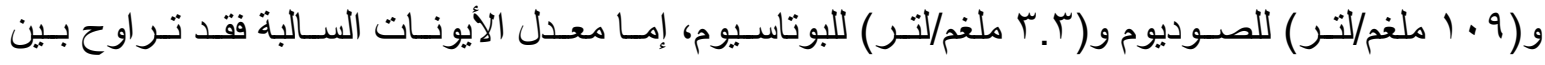

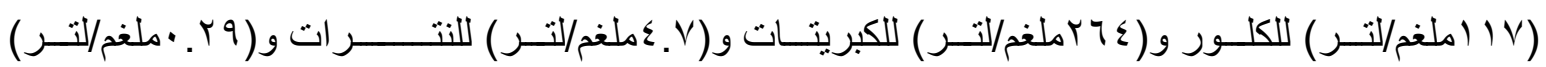
للفوسفات.

جدول (V) الخصائص النوعية لنماذج مياه نهر الغراف في منطقة الاراسة

\begin{tabular}{|c|c|c|c|c|c|c|c|c|c|c|c|c|c|}
\hline $\begin{array}{r}-\mathrm{PO}_{4} \\
\mathrm{mg} / \mathrm{l}\end{array}$ & $\begin{array}{r}-\mathrm{NO}_{3} \\
\mathrm{mg} / \mathrm{l}\end{array}$ & $\begin{array}{l}-\mathrm{SO}_{4} \\
\mathrm{mg} / \mathrm{l}\end{array}$ & $\begin{array}{r}{ }^{+} \mathrm{K} \\
\mathrm{mg} / \mathrm{l}\end{array}$ & $\begin{array}{l}{ }_{\mathrm{CL}} \\
\mathrm{mg} / \mathrm{l}\end{array}$ & $\begin{array}{l}{ }^{+} \mathrm{Na} \\
\mathrm{mg} / \mathrm{l}\end{array}$ & $\begin{array}{l}{ }^{+} \mathrm{Mg} \\
\mathrm{mg} / \mathrm{l}\end{array}$ & $\begin{array}{l}{ }^{+} \mathrm{Ca} \\
\mathrm{mg} / \mathrm{l}\end{array}$ & $\begin{array}{r}\text { ALK.A } \\
\text { Mg/1 }\end{array}$ & T.H & $\begin{array}{r}\text { T.D.S } \\
\mathrm{mg} / \mathrm{l}\end{array}$ & $\begin{array}{r}\text { E.C } \\
\text { ms }\end{array}$ & $\mathrm{PH}$ & \\
\hline.$r V$ & $\leqslant .0$ & Y7o & r. & 118.7 & 11. & $\varepsilon V_{.}$. & $9 \Lambda$. & 174 & $\varepsilon r \Lambda$ & VYA & 1.9. & $\vee .7$ & مقاطعـــة \\
\hline
\end{tabular}




\begin{tabular}{|c|c|c|c|c|c|c|c|c|c|c|c|c|c|}
\hline & $\varepsilon .7$ & $r V$. & r. & 110. & 1.0 & $\varepsilon V_{.1}$ & $9 \vee .0$ & IV. & $\varepsilon r V$ & $\Lambda \vee \varepsilon$ & 1.97 & $\vee . \wedge$ & 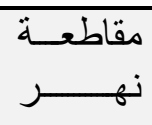 \\
\hline$\cdot T V$ & 0. & rov & $T . T$ & $111 . \varepsilon$ & 115 & $\varepsilon 7^{\circ}$ & $1 \cdots 0$ & 17. & $\varepsilon \varepsilon$. & דTY & 11.0 & $\vee . V$ & مقاطعـــة \\
\hline$\because . Y q$ & $\varepsilon . V$ & YTE & r.r & $11 \mathrm{~V}$ & 1.9 & $\leqslant 7 . V$ & 91.0 & $17 \varepsilon$ & $\varepsilon \mu$ & $\vee \vee q$ & $1.9 \mathrm{~V}$ & $V . V$ & المعدل \\
\hline
\end{tabular}

1 ـ ـوزارة البلايات والأشغال العامة، مديرية ماء واسط، قسم فحوصات المياه المختبرية (بياتات غير منشورة). r - وزارة البيئة، مديرية بيئة واسط، قسم التحاليل البيئية، (بياتات غير منثورة).

ولو قورنت هذِه النسب مع العناصر الأخرى لنتائج العينـات مع قيم الملحق ( (1)، فـإن المياه تكون صـالحة للشرب والاستخدامات الأخرى حسب معيار منظمة الصحة الدولية للمياه (WHO)، إلا إنها لا تنطبق عليها درجة الملوحة ونسبة الكالسيوم للحد المسموح بِهِ، إذ أظهرت نتائج العينات إن قيمتها مرتفعة نسبياً، والسبب في ذلك يعود إلى مياه المخلفات الزر اعية والصناعية ومياه الصرف الصحي التي تلقى في النهر على طول

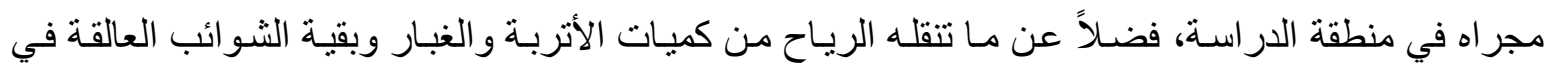
الهو اء، و هذا ما له اثر سلبي في رفع نسبة الايونات الموجبة والسالبة على حد سواء. ب ـ الأنهار الموسمية: ومن أهم الأنهار الموسمية في منطقة الدراسة هي:-

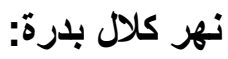
ينبع من الأجزاء الغربية لجبـال بشتكوه الإيرانيـة، ويتكون من إلتقاء فرعيه (كنجان جم) الذي ينحدر من الثمال الثرقي و(كافي رود) الذي ينحدر من الثـرق عند مخفر الطعـان مكونين كلال بدرة جنوب شرق ناحية زرباطية(؟r)، تقع مناطق مستجمع المياه لنهر كلال بدرة داخل الأر اضي العر اقية متمثلة بامتداد سلسلة جبال حمرين الجنوبي، ويعتمد نهر كلال بدرة في تغذيته على الأمطار الفصلية، إذ تُعد المقياس الأكثر أهمية في توازن المياه و إعادة تغذية الخزانات الجوفية في ذلك الجزء من منطقة الدراسـة، فيصل تصريفه الصيفي

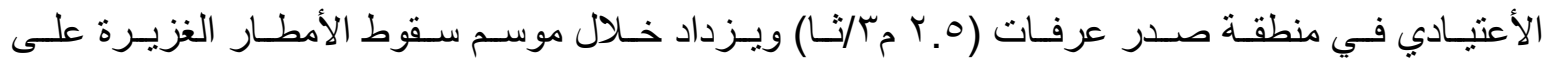

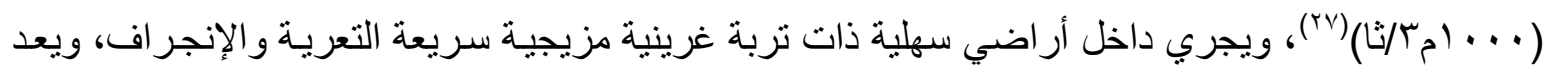
هذا النهر مورداً مهما للمياه في مناطق (بدرة وجصان وزباطية) رغم إن مياهـه تتسم بالتذبذب وارتفاع نسبة الملوحة فيها.

ومسن خـلال ملاحظة بيانـات الجدول (T)، نجد إن أعلى معدل سـنوي للتصـريف المـائي لنهر كلال بـدرة

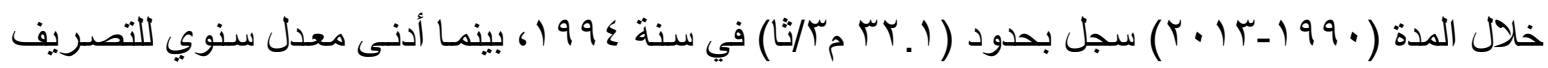

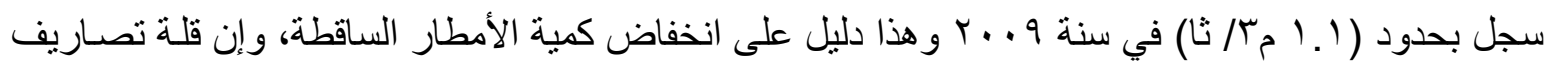
مياه نهر كلال بدرة جعل من مياهه غير صالحة للاستخدام بسبب إرتفاع تر اكيز الأمـلاح في مياهـه، مما أدى

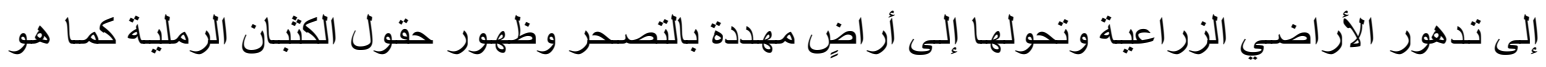

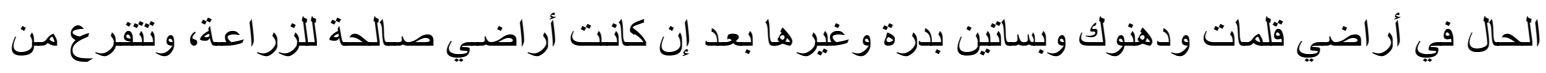

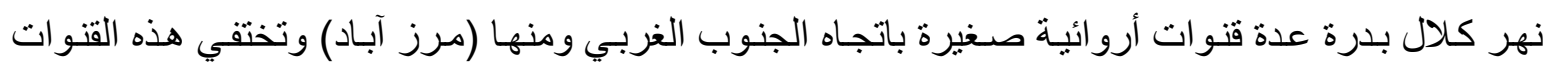
نتيجة لقلة كمية المياه المصرفة فيها، وذلك بسبب إرتفاع كمية التبخر الحاصل خلال فصل الصيف الطويل 
و إرتفاع نسبة تسرب المياه فيها إلى بـاطن الأرض. وبصورة عامـة فان كمية المـاء الآتيـة من الجبال و التتلال

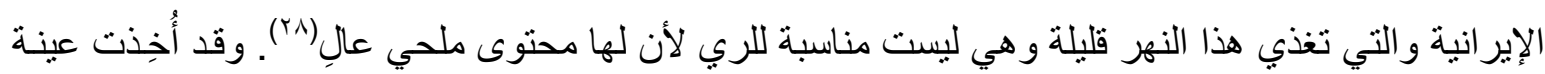
من مياه نهر كلال بدرة والمبينة في الجدول (^) كان الغرض منها هو معرفة الخصـائص الكيميائية للمياه

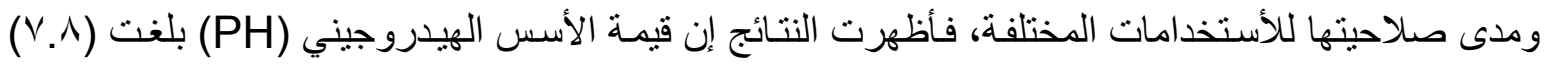
و هذا يدل على إن المياه قاعدية، أمـا قيمة التوصيل الكهربائي (E.C) فبلغت ( • (II مايكروموز/سم)، وهذا ما يؤدي إلى ظهور الأملاح على سطح التربة.

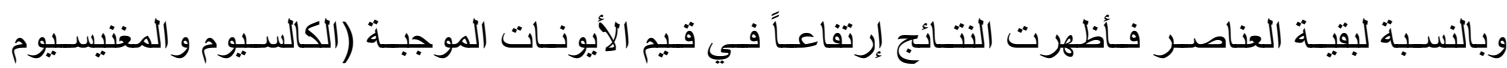

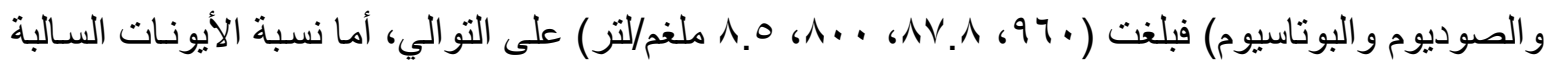

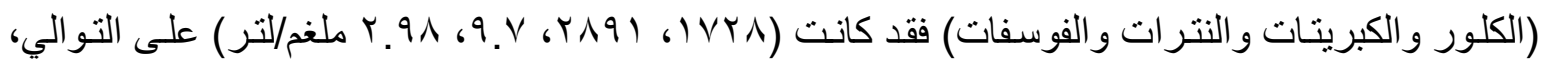

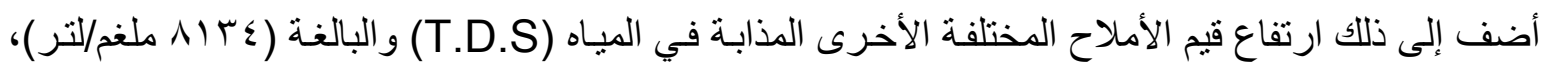
ومع مقارنة تلك النتائج مع قيم الملحق ( () نستتنج أن المياه غير صـالحة للأستخدامات المختلفة سو اء كانت البشرية أو الزر اعيـة والسبب في ذلك يعود إلى إرتفاع قيم الايونات الموجبـة على حسـاب الايونـات السـالبة نتيجة وصـول النهر إلى مرحلـة جفاف حـادة والنـاتج عن عدم توفر الميـاه فيـه ممـا أدى إلى تركز الأمـلاح

وارتفاع قيم بعض العناصر (ج").

جدول (^) الخصائص النو عية لمياه نهر كلال بدرة في منطقة الدراسة

\begin{tabular}{|c|c|c|c|c|c|c|c|c|c|c|c|c|c|}
\hline $\begin{array}{l}-\mathrm{PO}_{4} \\
\mathrm{mg} / \mathrm{l}\end{array}$ & $\begin{array}{r}-\mathrm{NO}_{3} \\
\mathrm{mg} / \mathrm{l}\end{array}$ & $\begin{array}{r}-\mathrm{SO}_{4} \\
\mathrm{mg} / \mathrm{l}\end{array}$ & $\begin{array}{r}{ }^{+} \mathrm{K} \\
\mathrm{mg} / \mathrm{l}\end{array}$ & $\begin{array}{l}-\mathrm{CL} \\
\mathrm{mg} / \mathrm{l}\end{array}$ & $\begin{array}{l}{ }^{+} \mathrm{Na} \\
\mathrm{mg} / \mathrm{l}\end{array}$ & $\begin{array}{l}{ }^{+} \mathrm{Mg} \\
\mathrm{mg} / \mathrm{l}\end{array}$ & $\begin{array}{l}{ }^{+} \mathrm{Ca} \\
\mathrm{mg} / \mathrm{l}\end{array}$ & $\begin{array}{r}\text { ALK.A } \\
\mathrm{Mg} / 1\end{array}$ & T.H & $\begin{array}{r}\text { T.D.S } \\
\mathrm{mg} / \mathrm{l}\end{array}$ & $\begin{array}{r}\text { E.C } \\
\text { ms }\end{array}$ & $\mathrm{PH}$ & \\
\hline r.91 & १.V & r/q) & 1.0 & IVYA & A... & $\Lambda V . \wedge$ & 97. & 17. & $r_{0} \varepsilon_{0}$ & צוא & राl. & V.A & و الإبداعة حمزة \\
\hline
\end{tabular}

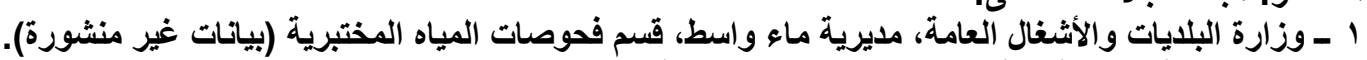

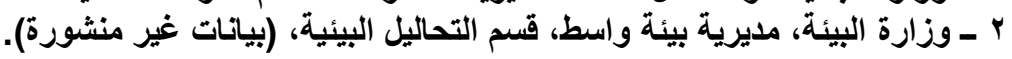

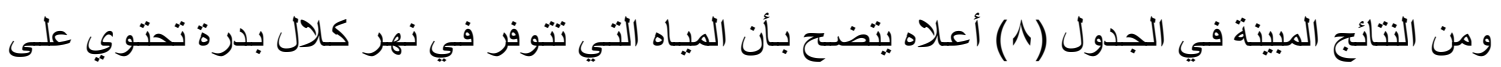
كميات كبيرة من الأمـلاح وبصورة عامـة تجعلها غير صـالحة للشـرب و لأغر اض الري وإن كميـة الأمـاح

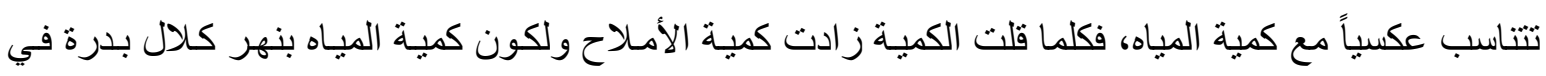
تتـاقص مستمر لأنقطاع الميـاه مـن رافد كنجـان جم المغذي الرئيس لكـلال بدرة فعليه نتوقع إن تزيد كميـة الأملاح في المياه المتوفرة أكثير من الكميات المبينة أعلاه(·"). نهر كلال ترساخ: ينبع من الحدود الإيرانية على بعد (•Vكم) عن الحدود العر اقية، تتجمع فيه المياه من مصسادر متعددة أهمها مياه الأمطار ومياه ينابيع المراوح الطموية (كعين لازم و عين مسعود) شتاءاً اللنان تعدان من العيون النشطة التي تغذي نهر كلال ترساخ، في حين تقل كمية المياه في فصل الصيف وتصبح مياهـه مالحة غير صـالحة للأستخدام وذلك بسبب إختلاطها بمياه ملحية داخل الحدود الإير انيـة، وعند دخوله الأر اضـي العر اقيـة يتفرع إلى عدة فروع، تقع أراضيه بين منطقتي مندلي وبدرة("r)، ويتر اوح عرض و ادي نهر كلال ترسـاخ بين

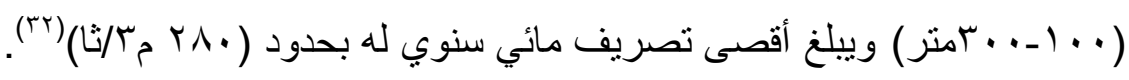


ويلاحظ من خلال تحليل الجدول (7)، وجود إختلاف في معدلات التصريف المـائي السنوي لنهر كلال

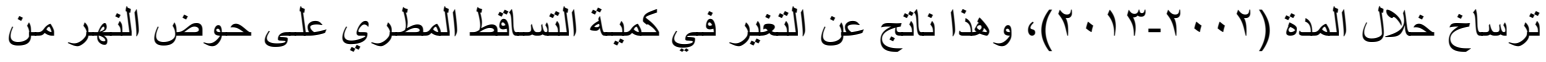

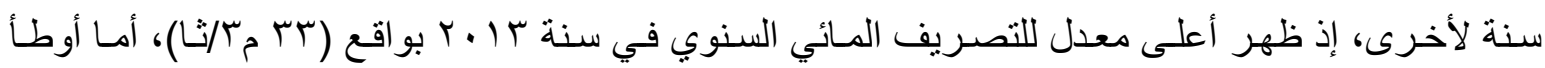

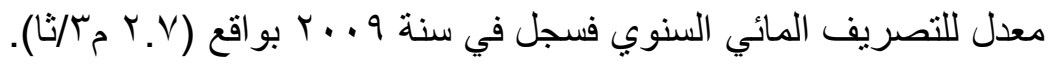
ولغرض التعرف على نوعية مياه نهر كلال ترساخ وأستخدامها للري تم أخذ عينة ميـاه مبينة في الجدول (9) فأظهرت نتائجها إن قيمة الأسس الهيدروجيني (PH) بلغت (9.9) وهذا يدل على إن المياه قاعدية، أمـا

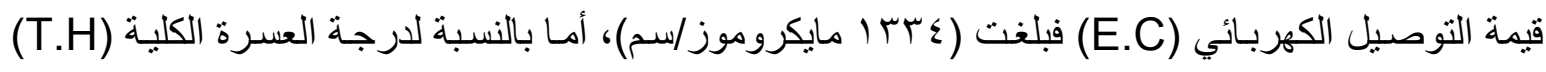

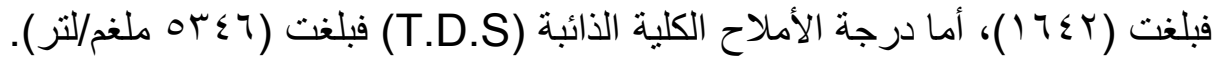
جدول (9) الخصائص النوعية لمياه نهر كلال ترساخ في منطقة الاراسة

\begin{tabular}{|c|c|c|c|c|c|c|c|c|c|c|c|c|c|}
\hline $\begin{array}{l}-\mathrm{PO}_{4} \\
\mathrm{mg} / \mathrm{l}\end{array}$ & $\begin{array}{l}-\mathrm{NO}_{3} \\
\mathrm{mg} / \mathrm{l}\end{array}$ & $\begin{array}{l}-\mathrm{SO}_{4} \\
\mathrm{mg} / \mathrm{l}\end{array}$ & $\begin{array}{c}{ }^{+} \mathrm{K} \\
\mathrm{mg} / \mathrm{l}\end{array}$ & $\begin{array}{l}-\mathrm{CL} \\
\mathrm{mg} / \mathrm{l}\end{array}$ & $\begin{array}{l}{ }^{+} \mathrm{Na} \\
\mathrm{mg} / \mathrm{l}\end{array}$ & $\begin{array}{l}{ }^{+} \mathrm{Mg} \\
\mathrm{mg} / \mathrm{l}\end{array}$ & $\begin{array}{l}{ }^{+} \mathrm{Ca} \\
\mathrm{mg} / \mathrm{l}\end{array}$ & $\begin{array}{c}\text { ALK.A } \\
\text { Mg/1 }\end{array}$ & T.H & $\begin{array}{l}\text { T.D.S } \\
\mathrm{mg} / \mathrm{l}\end{array}$ & $\begin{array}{l}\text { E.C } \\
\mathrm{s} / \mathrm{m}\end{array}$ & $\mathrm{PH}$ & الكوصن \\
\hline 1.14 & $V . r$ & $1 \leqslant \ldots$ & $v_{.}$. & $q \wedge$. & 110 & vo.. & $\vee q$. & $17 \%$ & $17 \leqslant Y$ & ד & צ & $v . q$ & الهشيمعة \\
\hline
\end{tabular}

1 ـ وزارة البلايات والأشغال العامة، مديرية ماء واسط، قسم فحوصات المياه المختبرية (بيانات غير منشورة).

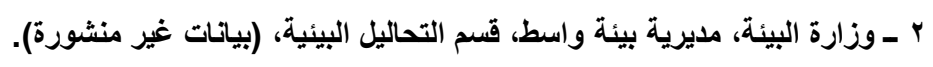
ومن الملاحظ في نتائج الجدول أعلاه بتبين هنالك إرتفاعاً في قيم الأيونـات الموجبـة (الكالسبوم و المغنيسيوم

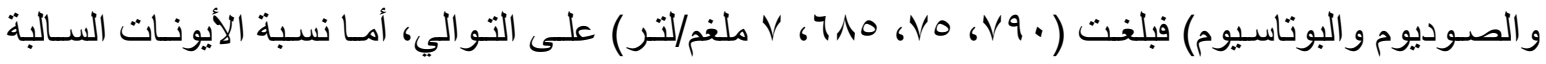

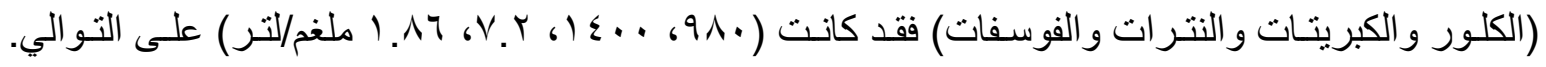
ومع مقارنة تللك النتائج مع قيم الملحق ( ) نستتنج أن المبـاه غير صـالحة للأسـتخدامات المختلفة سواء كانت

$$
\text { البشرية أو الزراعية. }
$$

ج ـ المنخفضات الأرضية السطحية: تمثنل المنخفضـات الأرضـية أمـاكن جيدة لخزن الميـاه في وقت أرتفـاع مناسيبها في الأنهار الدائميـة و الموسمية أثناء موسم الفيضان، و إطلاقها في موسم شحة المياه إلى الأنهار، وتتمثل هذه المنخفضـات بهور الثويجة الذي يقع جنوب شرق قضاء بدرة ويستمد مياهه من نهر كلال بدرة.

\section{- منخفض هور الشويجة:}

يعد هور الثويجة أحد أهو ار محافظة واسط، وهور منخفض طبيعي مستطيل الثكل يمتد موازاة نهر دجلة

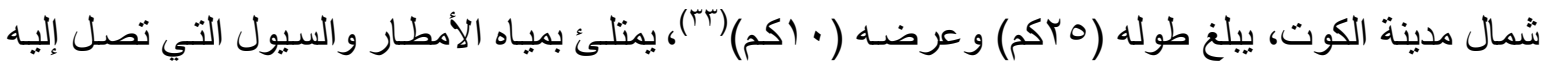
من الثرق عبر كلال بدرة وكلال ترسخ من الثـمال مروراً بمنخفض النهروان الذي يقوم بتصريف المياه الزائدة من نهر الوند في محافظة ديالى ومياه الثغرات التي تحدث في سداد نهر دجلة بين العزيزية والكوت

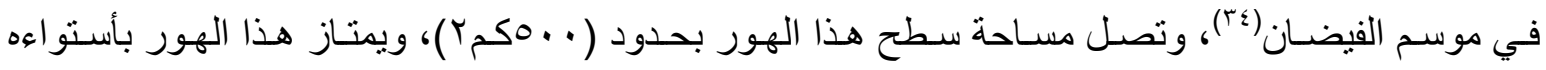

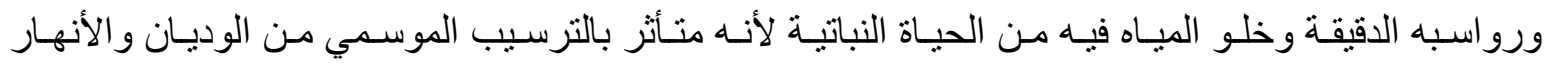
الموسمية لهذا أصبح سطح الهور خالي من الغطاء النباتي. 
أما عن نوعية مياه هور الثويجة، فقد تبين من نتائج التحليل المختبري المدونـة في جدول ( • () إن قيمة

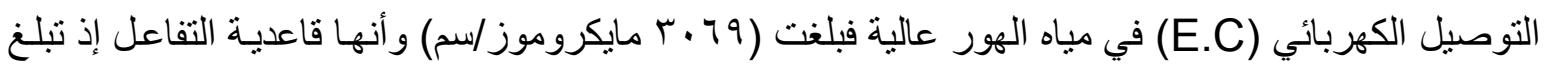

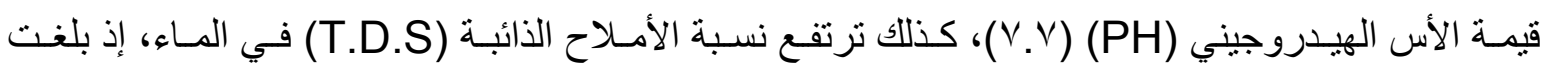

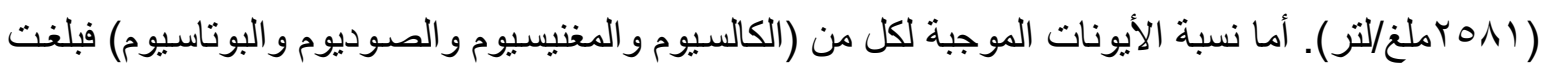

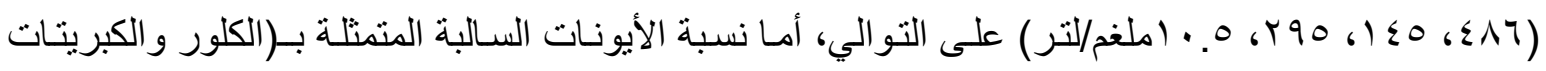

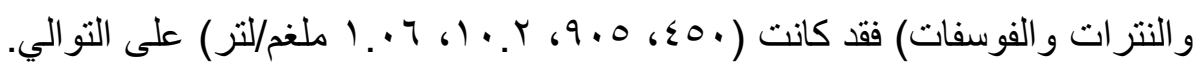

جدول (·) (1)

الخصائص النوعية لمياه هور الثويجة في منطقة الاراسة

\begin{tabular}{|c|c|c|c|c|c|c|c|c|c|c|c|c|c|}
\hline $\begin{array}{l}-\mathrm{PO}_{4} \\
\mathrm{mg} / \mathrm{l}\end{array}$ & $\begin{array}{l}-\mathrm{NO}_{3} \\
\mathrm{mg} / \mathrm{l}\end{array}$ & $\begin{array}{l}-\mathrm{SO}_{4} \\
\mathrm{mg} / \mathrm{l}\end{array}$ & $\begin{array}{r}{ }^{+} \mathrm{K} \\
\mathrm{mg} / \mathrm{l}\end{array}$ & $\begin{array}{c}-\mathrm{CL} \\
\mathrm{mg} / \mathrm{l}\end{array}$ & $\begin{array}{l}{ }^{+} \mathrm{Na} \\
\mathrm{mg} / \mathrm{l}\end{array}$ & $\begin{array}{l}{ }^{+} \mathrm{Mg} \\
\mathrm{mg} / \mathrm{l}\end{array}$ & $\begin{array}{l}{ }^{+} \mathrm{Ca} \\
\mathrm{mg} / \mathrm{l}\end{array}$ & $\begin{array}{r}\text { ALK.A } \\
\text { Mg/1 }\end{array}$ & T.H & $\begin{array}{r}\text { T.D.S } \\
\mathrm{mg} / \mathrm{l}\end{array}$ & $\begin{array}{l}\text { E.C } \\
\text { s/m }\end{array}$ & PH & الفكص أســــم \\
\hline 1.97 & $1 \cdot . r$ & 9.0 & $1 . .0$ & $\leqslant 0$. & rqo & $1 \leqslant 0$ & \& & 17. & 1.40 & $r O \wedge 1$ & 5.79 & V.V & 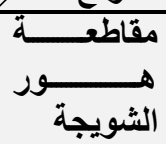 \\
\hline
\end{tabular}

المصدر: الباحث بالاعتماد على :- الماتل

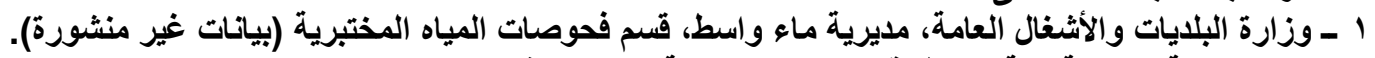
r - ـ ـ وزارة البيئة، مديرية بيئة واسط، قسم التحاليل البيئية، (بيانات غير منشورة).

r

تعـد الميـاه الجوفيـة مـن العوامـل الرئيسية المسؤولة عـن ظهـور الأر اضـي المتأثرة بالملوحـة في منطقة الدر اسـة، وذلك بسبب إرتفاع مناسيب الميـاه الأرضية المالحة وقربها من سطح التربـة، جدول ( (' ) إذ إن قرب هذه المياه من سطح التربـة وتأثر هـا بفعل الخاصية الثـعرية نتيجة التبخر العالي بسبب إرتفاع درجات الحرارة أدى إلى تملح الترب وتكوين الأر اضي المتأترة بالأملاح، خصوصاً في الأراضي التي يكون منسوب الماء الأرضي ضمن نطاق العمق الحرج (Critical depth)(

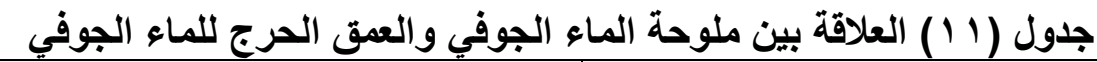

\begin{tabular}{|c|c|}
\hline العمق الحرج للماء الجوفي (متر)|*) & ملوحة الماء الجوفي (غرام/لتر) \\
\hline $1 . Y=1.9$ & $r-1$ \\
\hline$r . r=1 . r$ & $0-r$ \\
\hline$r .0 . Y . r$ & A.0 \\
\hline r.q.r.o & $1 \cdot-1$ \\
\hline
\end{tabular}

المصدر: أحمد حيدر الزبيدي، ملوحة التربة (الأسس النظرية والتطبيقية)، طץ، دار الحكمة

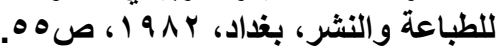

وتتوزع المياه الجوفية في أجزاء مختلفة من قضـاء بدرة، وتكون واهون على نوعين: النوع الأول يتمثل بمياه الينابيع و العيون الطبيعية التي نوجد بمحاذاة منطقة أقدام التلال لسلسلة جبال حمرين الجنوبي لأنكثـاف طبقات الطين التي تعلوها طبقات من الحصى و الرمل الحاملة للمياه الجوفية وتصرف مياه هذه العيون بأتجاه الوديان الموسمية المنتشرة في المنطقة وتصب معظمها في نهر كلال بدرة(بr)، كذللك فقد رصدت (عين الفهوديات)

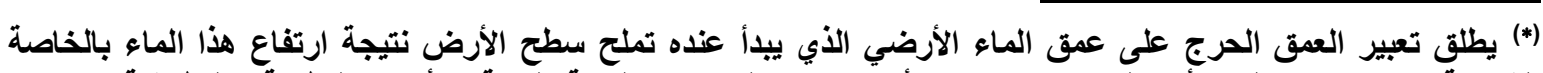

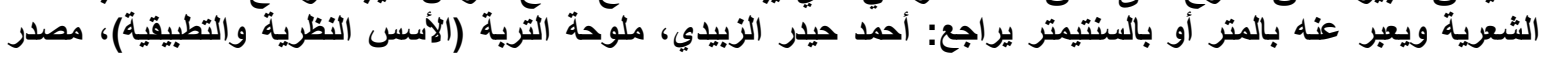

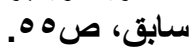


الو اقعة في جنوب شرق قضاء بدرة والتي تصرف مياهها هي الأخرى في الوديان الموسمية المنسـابة بأتجاه

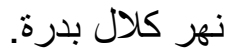

و النوع الثاني للمياه الجوفيـة في قضـاء بدرة فيتحدد بميـاه الآبـار الجوفيـة المنتشرة في القضـاء، و التي لها أهمية كبيرة فأنها تعد المخزون المائي الجوفي المكمل لمشاريع الري، إذ تعوض إلى حد مـا النقص الحاصل في الموارد المائية، وقد حفرت مجموعة من الآبار لاستخر اج المياه الجوفية والاستفادة منها في الري، وتتميز مياه الآبـار لحوض بدرة بوجود منسوبان للميـاه الجوفيـة، وهمـا المكمن المفتوح الذي تمثله ترسبات الزمن الرباعي المنتشرة على عموم مساحة الحوض، ومن أبرز الآبـار الجوفية لهذا المكمن هي (بئر الهشيمة وبئر عرفات وبئر الغزالي وبئر قرية عين غوار) و المكمن المحصور متمثنا بترسبـات الزمن الربـاعي في الجزء الثمالي وتكوين المقداديـة في الجزء الجنوبي الثرقي منه، وأبرز الآبار في هذا المكمن هي (بئر بدرة القديمة وبئر الكرمشية وبئر زرباطية وبئر بساتين بدرة)، يتز ايد سمك المكمن المفتوح باتجـاه الغرب مما يؤثر على

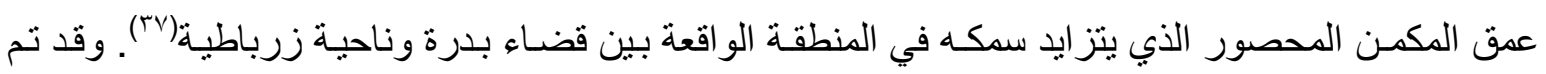
تحليل ثلاثة نماذج من مياه الآبار المنتشرة في قضاء بدرة، جدول (r ( ) وتبين من خـلال نتائج التحليلات إن

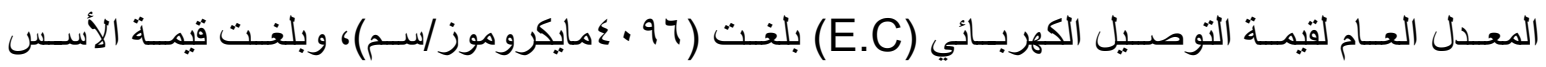

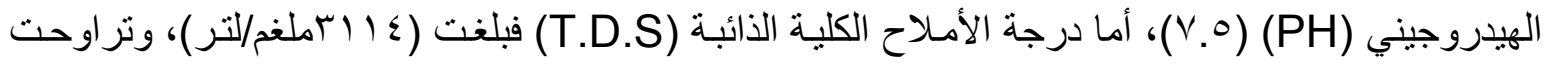

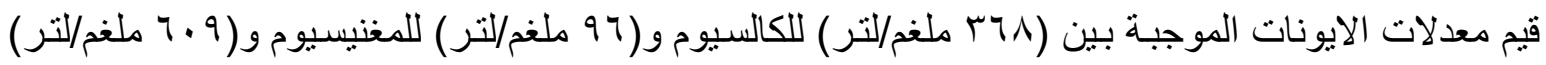

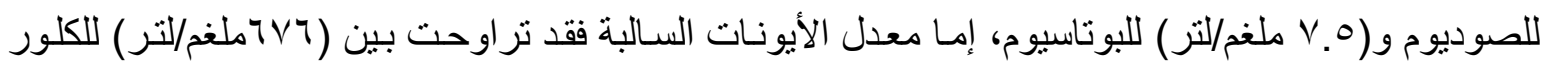

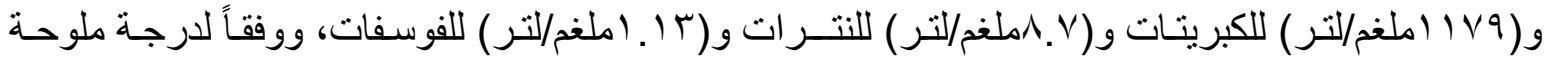
الميـاه فـي هـذه الآبـار فأنهـا لاتصـلح للثـرب ويمكـن إســتخدامها لسـقي البسـاتين والمزروعـات ورعـي الحيو انات(r)(

جدول (r ا) الخصائ النوعية لنماذج مياه الآبار في منطقة الاراسة

\begin{tabular}{|c|c|c|c|c|c|c|c|c|c|c|c|c|c|}
\hline $\begin{array}{l}-\mathrm{PO}_{4} \\
\mathrm{mg} / \mathrm{l}\end{array}$ & $\begin{array}{c}-\mathrm{NO}_{3} \\
\mathrm{mg} / \mathrm{l}\end{array}$ & $\begin{array}{c}-\mathrm{SO}_{4} \\
\mathrm{mg} / \mathrm{l}\end{array}$ & $\begin{array}{c}{ }^{+} \mathrm{K} \\
\mathrm{mg} / \mathrm{l}\end{array}$ & $\begin{array}{l}-\mathrm{CL} \\
\mathrm{mg} / \mathrm{l}\end{array}$ & $\begin{array}{c}{ }^{+} \mathrm{Na} \\
\mathrm{mg} / \mathrm{l}\end{array}$ & ${ }_{\mathrm{mg} / \mathrm{I}}^{+\mathrm{Mg}}$ & $\begin{array}{c}{ }^{+} \mathrm{Ca} \\
\mathrm{mg} / \mathrm{l}\end{array}$ & $\begin{array}{c}\text { ALK.A } \\
\mathrm{Mg} / 1\end{array}$ & T.H & $\begin{array}{l}\text { T.D.S } \\
\text { mg/l }\end{array}$ & $\begin{array}{l}\text { E.C } \\
\text { ms }\end{array}$ & PH & \\
\hline 1.0 & V.Y & $11 \%$ & 7. & YYE & -VA & $1 \% 4$ & $\varepsilon \cdot r$ & 171 & 1075 & Yq1. & rqr. & $V .0$ & مرمزيارة \\
\hline 1.99 & 9.7 & $9 \leq 7$ & 1.0 & $V \cdot 0$ & 70. & $\Delta V . r$ & r & $r \ldots$ & $1 \cdot r \cdot$ & 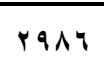 & $\varepsilon .0$. & V.V & دقاطعة \\
\hline 1.87 & $9 . r$ & $1 \leq 0 \leq$ & ^.• & $V \ldots$ & $7 \ldots$ & $9 \leq .7$ & 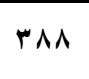 & 17. & $1 \% 4$. & $r \leq \varepsilon q$ & 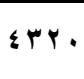 & V.r & ققماطعة \\
\hline $1.1 \%$ & ^.V & 1189 & $V .0$ & 787 & 7.9 & 97 & พч⿱ & 187 & $\mid$ I & MI & $\varepsilon .97$ & $V .0$ & المعدل \\
\hline
\end{tabular}

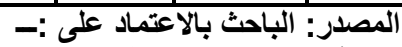

1 ـ وزارة البلايات والأشغال العامة، مديرية ماء واسط، قسم فحوصات المئل المياه المختبرية (بيانات غير منشورة). r ب - وزارة البيئة، مديرية بيئة واسط، قسم التحاليل البيئية، (بيانات غير منشورة).

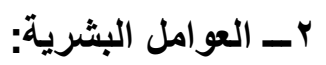

لا يقتصر ظهور تملح التربة على العوامل الطبيعية وإنما هنالك عوامل بشرية أسهمت في و لا تز ال تسهم في نشوء هذه المشكلة في منطقة الدراسة وتر اكمها والتي تتمثل بدور الإنسان ومن خـلال إدارته السيئة للتربـة و المياه، إلى المساهمة في تدهور وتملح التربة، ومن خـلال الدراسـة الميدانية لوحظ إن معظم الترب متملحة 
أو متأثرة بالأملاح بسب الإرواء الخاطئ من خلال زيادة مساحة الزراعة الإروائية دون الأخذ بنظر الاعتبار

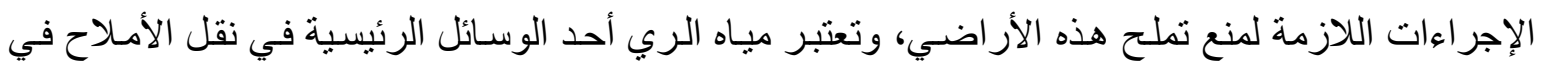
تربـة منطقة الدر اسـة، وذلك من خـلال كميـات الأمـلاح المنقولـة بو اسطة ميـاه الري (*)، و لاسيما وان جميع مصسادر مياه الري في منطقة الدر اسـة تحتوي على نسب متفاوتـة من الملوحة، وتثير أحدى الدراسـات إن ملوحة التربة تزداد بشكل ملحوظ مـع زيادة درجة ملوحة مياه الري، إلا إن تقليل المدة بين الريـات تسـاعد

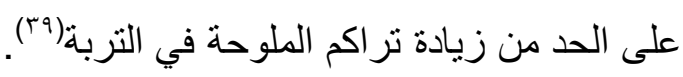

و إن عدم وجود شبكة مبـازل ذات كفاءة عاليـة فضـلاً عن عدم وجود أو محدوديـة الصـرف الطبيعي في الأر اضي ذات الإنحدار الضئيل يعد السبب الرئيسي في تر اكم المياه الأرضية وإرتفاع مستو اها باتجاه سطح التربـة، وهذا مـا يسمح بصعود المـاء إلى السطح عن طريق الخاصية الثـعرية إذ يتبخر هناك تاركاً ور اءه

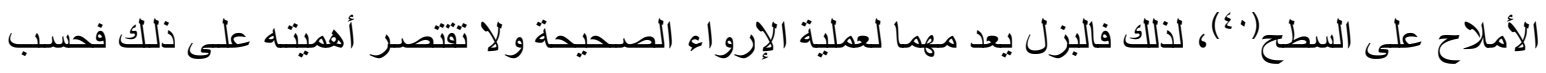

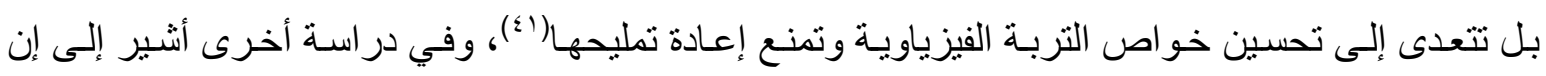

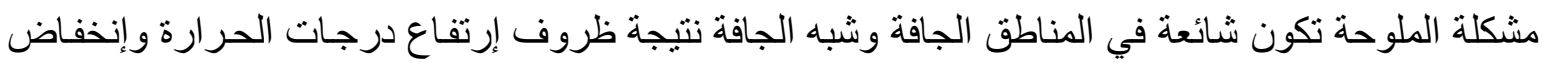
معدلات الأمطار السـاقطة وظروف التبخر العـالي للمياه الأرضية المالحة، كمـا أشـارت أيضـاً إلى إن التملح يحصل نتيجة استعمال المياه بشكل مفرط في المناطق المروية وحصول حالات الإغداق بسبب إعتماد طر ائق

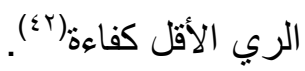

\section{المبحث الثاني- التباين المكاني لمعدلات هلوحة التربة في هنطقة الدراسة}

تتباين معدلات ملوحة التربـة مكانياً بين مختلف جهات منطقة الدر اسـة تبعاً لطبيعـة العو امل المسـاعدة في

نشو عها، ويمكن توضيحها بالثكل الآتي:-

1ـتـوبة كتتوف الأنــار:

تتير بيانات الملحق (Y) إن المعدل العام لقيم الملوحة في كلا الأعماق لتربـة كتوف الأنهار بلغ (90.0) مليموز/سـ، وتشـهـ تباينـات مكانيـة بين الوحدات الإداريـة لهذه التربـة، بلـغ أعلى معدل لها في ترب ناحيـة

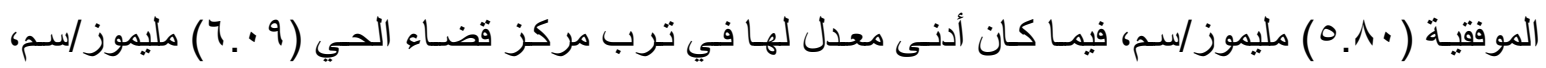
خريطة (0)، وبحسب تصنيف درجة الملوحة في جدول (Y) تعد ترب متوسطة الملوحة، ورغم ذلك تمتاز تربة كتوف الأنهار بأنها ترب قليلة الملوحة بالمقارنـة مـع ترب الأحو اض و المستنقعات في منطقة الدراسـة التي تليها، ويرجع سبب ذللك لقربها من نهر الغر اف الذي بحقق لها بزلاً طبيعياً لغسل للتربـة بشكل دائمى ممـا

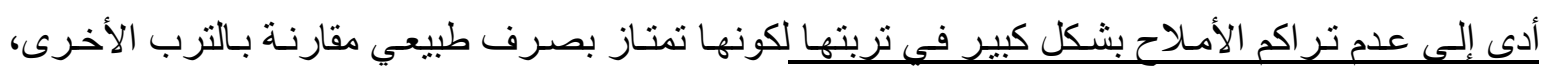
فضلاً عن بعد المياه الأرضية في ثربتها عن السطح("؟)، وتتوزع بحسب الأعماق المدروسة كما بأتي:

(*) أمكن أن تساهم مياه الري في عملية التملح من خلال تأثيرين:-

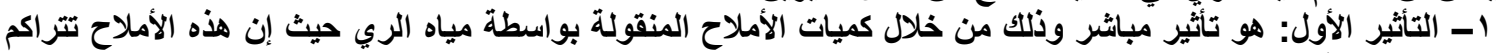

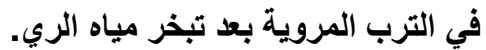

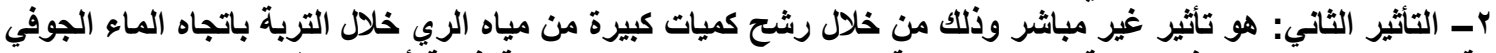

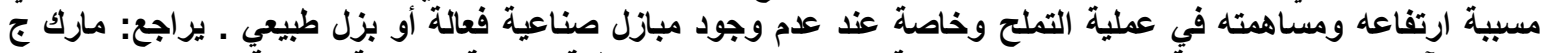

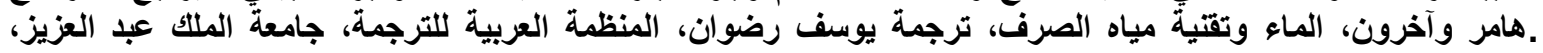


العمق الأول ( •-• اسم): يتضح من نتائج الملحق (Y) إن معدل قيم الملوحة لتربـة كتوف الأنهار ضمن هذا

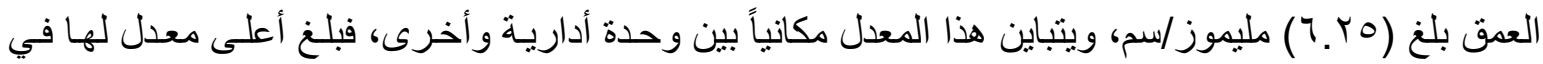
ترب مركز قضاء الحي (9 • . 7) مليموز/سم، وأدنى معدل لها في ترب ناحية الموفقية (•^.ـ) مليموز/سم.

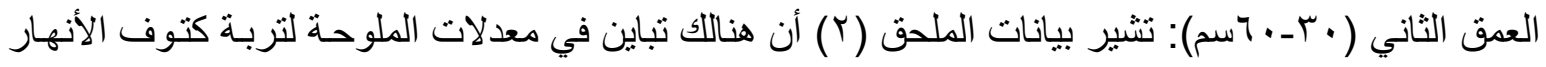

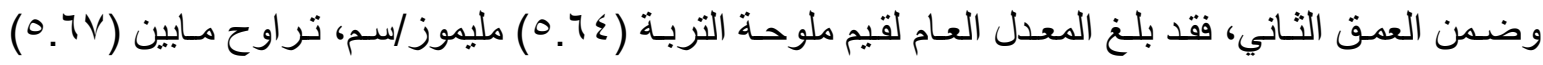
مليموز/سم لتربة مركز قضاء الحي و( • 7.0) مليموز /سم لتربة ناحية الموفقية. ثاـتربة أحواض الأنهار:

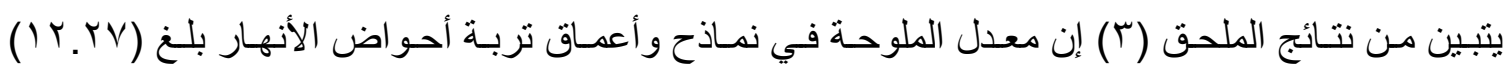
مليموز/سم، ويعني ذلك إن هذه التربة ذات ملوحة عالية حسب معيار ملوحة التربة المشار إليه في جدول (r)

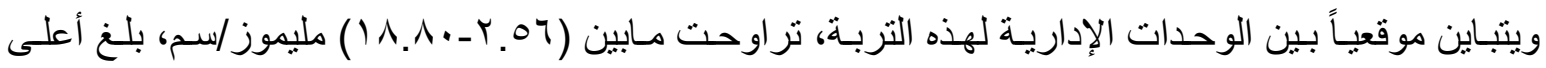

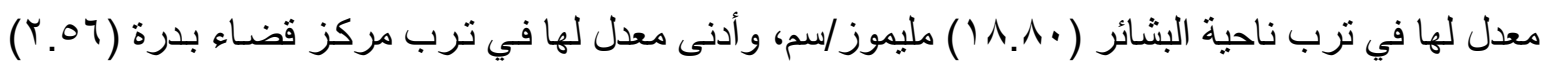
مليموز/سم، خريطة (0)، ويمكن إن يعزى سبب ارتفاع معدل الملوحة بشكل كبير في ترب ناحيـة البشائر إلى موقعها المنخفض الذي سـاعد على إرتفاع مسـتوى المـاء الأرضـي المـالح، فضـلاً عن الظــروف المــــاخية المتمثلة في قلة التساقط وارتفاع كمية التبخر و لاسيما في أثشهر الصيف، ممـا سبب زيـادة نشـاط عمليـة تر اكم الأملاح في التربة، وتتوزع بحسب الأعماق المدروسة كما يأتي: خريطة (0) التباين المكاني لمعدلات ملوحة التربة (مليموز/سم) في منطقة الاراسة لهربة
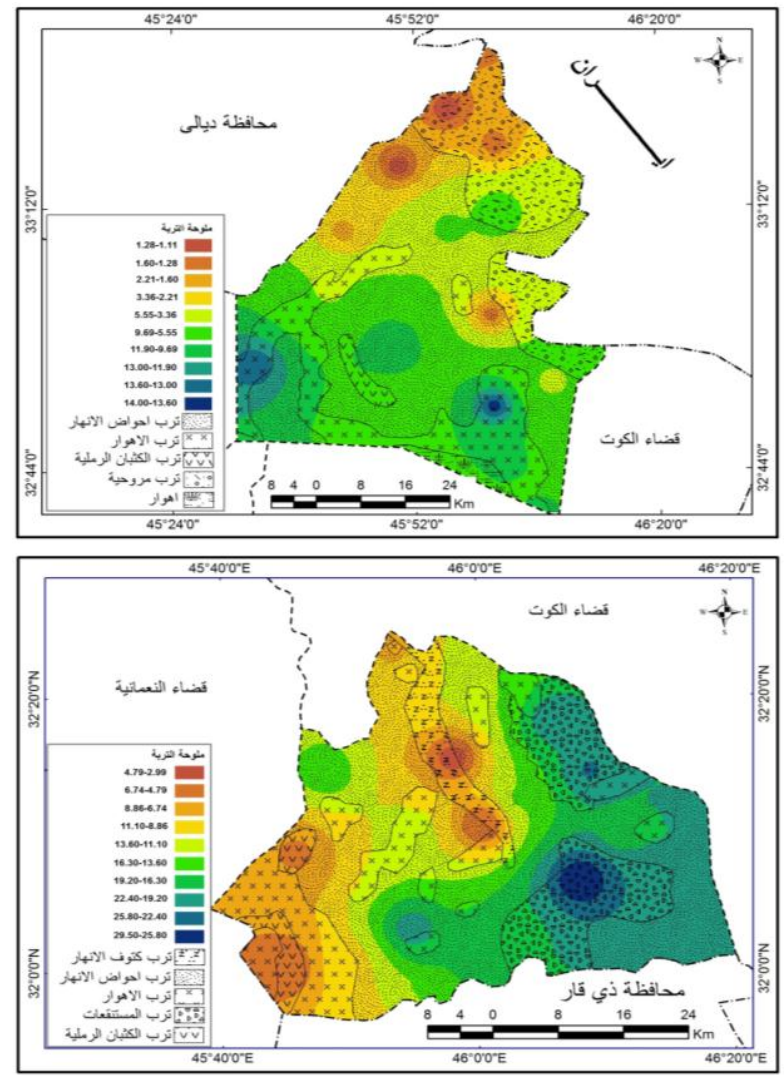

المصدر: الباحث اعتماداً على برنامج Arc GIS map.9.3 و الملاحق (ץ، זّ، ؛، ه، ؟، V).

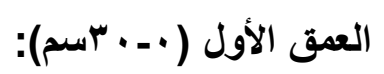


بلغ معدل ملوحة التربة ضمن هذا العمق (r7. I I ) مليموز/سم، ويتباين مكانياً بين مو اقع التربـة المدروسـة،

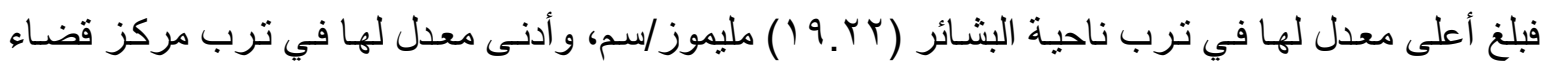

بدرة (Y.Y. (Y) مليموز/سم، ينظر ملحق (r). العمق الثاني ( • ؟- • آسم): يوضح الملحق (ץ) أن معدل العمق الثاني لقيم الملوحسة في تربـة أحو اض الأنهار

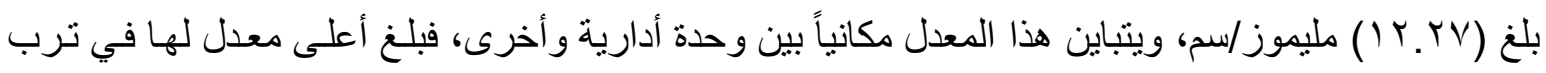

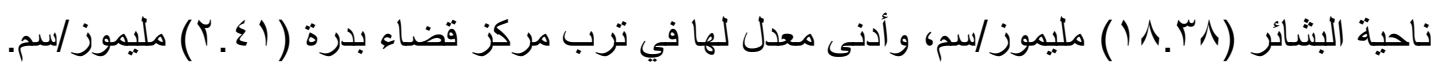

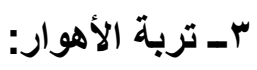
يلاحظ من نتائج الملحق (ع) إن تربـة الأهوار تقع ضـمن الترب عالية الملوحـة حسب مؤشر ات ملوحسة

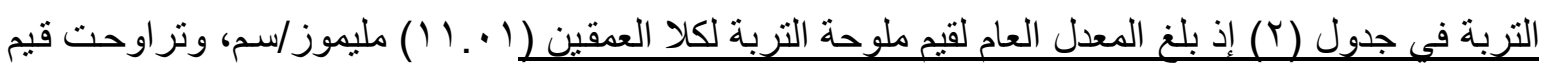

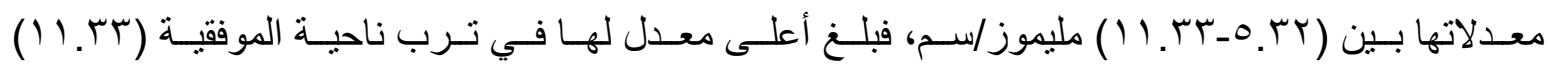
مليموز/سم، وأدنى معدل في ترب ناحية جصان (79. • (1) مليموز/سم، خريطة (0)، ويمكن إن تعزى أسباب ارتفاع معدلات الملوحة في هذه التربة إلى ظروف الصرف الرديئة، و إرتفاع الماء الأرضي المسالح وقربـه من

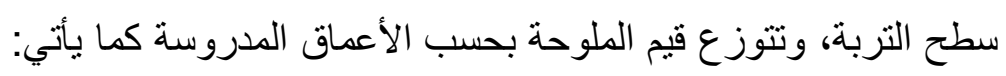

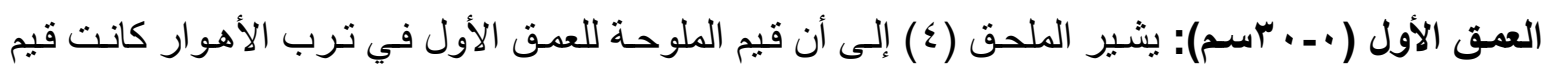

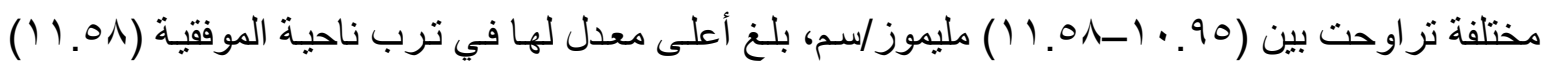
مليموز/سم، وأدنى معدل لها في ترب ناحية جصان (90.9 • (1) مليموز/ سم.

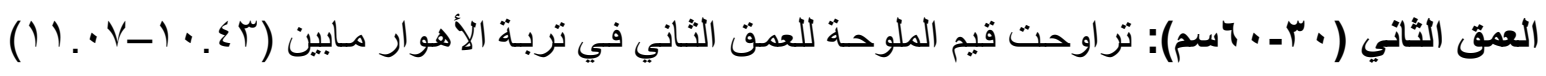

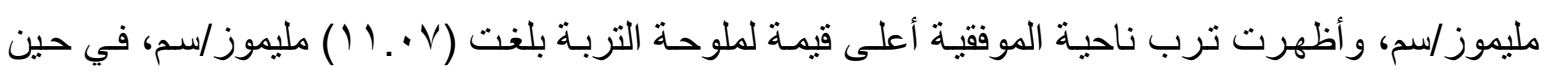

كانت أقل قيمة لملوحة التربة في ترب ناحية جصان بلغت (سع ـ ـ ( ) مليموز/سم، ينظر ملحق (ع).

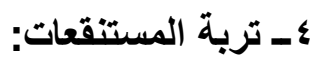

تتصف تربـة المستنقعات بأرتفاع معدلات الملوحـة فيها، فيتبين من خـلال بيانـات الملحق (0) إن المعدل

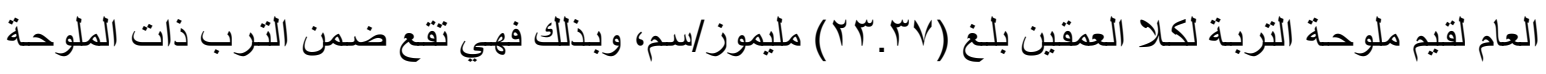
العالية جداً، ويعزى سبب ذلك كونها منـاطق منخفضـة نسبياً تبدأ فيها عملية الترسيب بشكل مر احل حيث

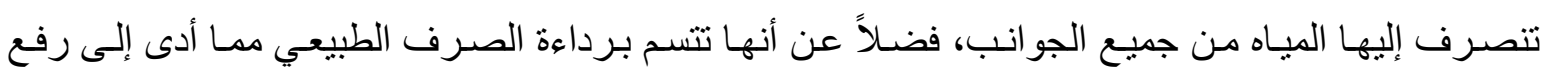
منسوب المياه الأرضية وصعودها بالخاصية الثـعرية فتمتزج مـع المياه السطحية فتبقى على سطح التربـة ونتيجـة لإرتفاع درجات الحرارة في فصل الصيف و التبخر الثـديد ممـا يؤدي إلى تبخر هذه الميـاه تاركاً

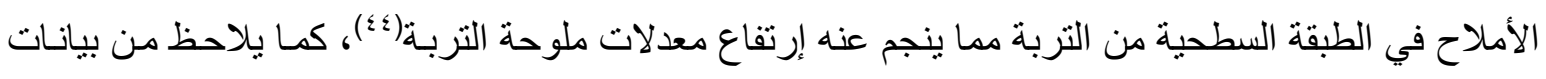
الملحق (0) تفاوت قيم الملوحة بين الوحدات الإدارية لهذه التربـة، إذ تراوحت معدلات الملوحـة لكلا العققين

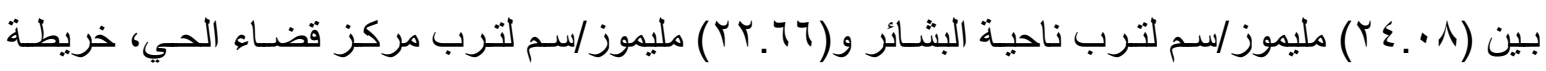
(0)، وتتوزع بحسب الأعماق المدروسة كما يأتي: 
العمق الأول ( • . - بسـم): يظهر مـن بيانـات ملحق (0) بأن قيم الملوحة في هذا العمق قد تراوحت مـابين

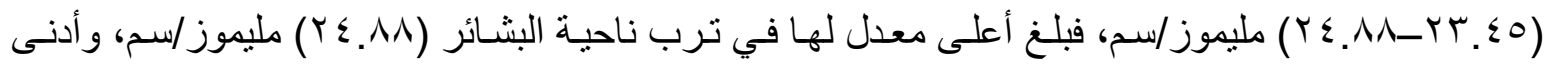

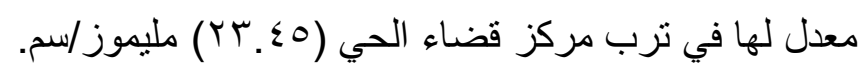

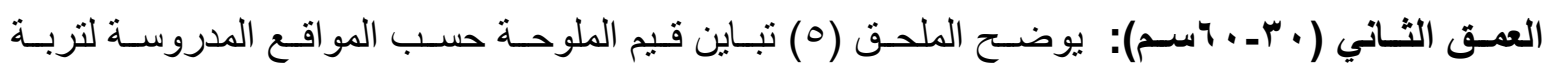

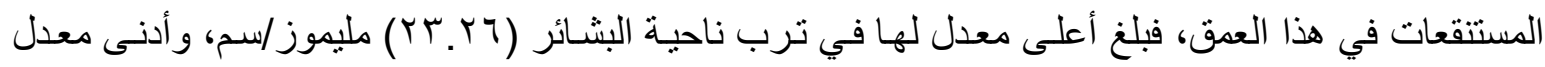
لها في ترب مركز قضاء الحي (T/1. آץ) مليموز/سم.

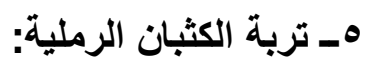

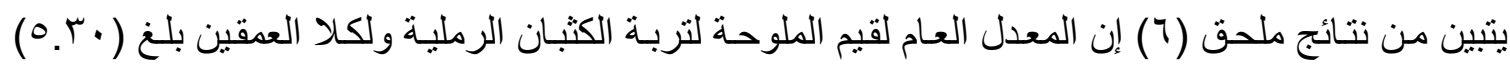
مليموز/سم، ينظر خريطة (0)، وتصنف بكونها متوسطة الملوحة وفق درجات ملوحة التربـة الموضحة في جدول (Y)، يعود سبب إنخفاض نسبة الأملاح في هذه التربة قياساً بترب أحواض الأنهار وترب الأهوار إلى لى طبيعـة التربـة ونسـتها الخشنـة، كذللك إنخفاض مستوى المياه الجوفيـة التي تعد مصدر الأملاح على سطح التربة، وقد تباينت قيمها بين المو اقع المختلفة وكذللك بين الأعماق ضمن الموقع الواحد نفسه وكالآتي:

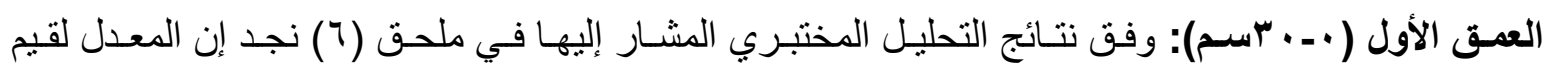

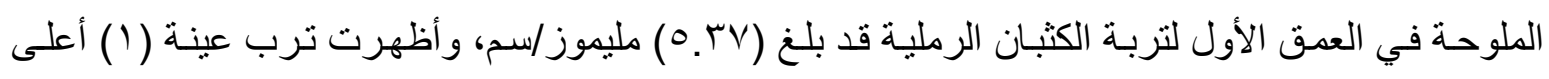

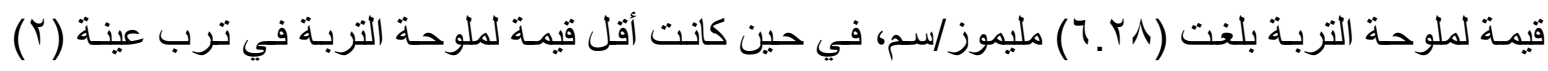

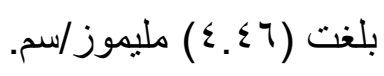

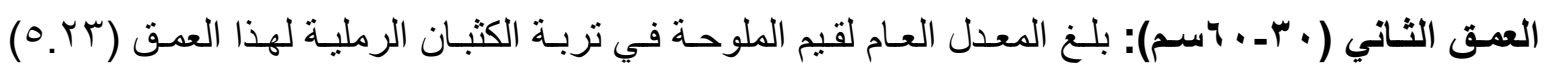
مليموز/سم، و أظهرت ترب عينة (1) أعلى قيمة لملوحة التربة بلغت (9 ( ـ ) مليموز /سم، في حين كانت أقل

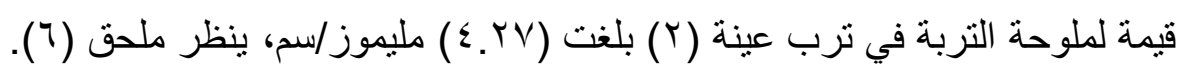
צ- تربة المراوح الغرينية: يتبين من الملحق (V) لنماذج تربة المراوح الغرينية، بـأن المعدل العام لملوحة التربـة في كلا العمقين بلـغ

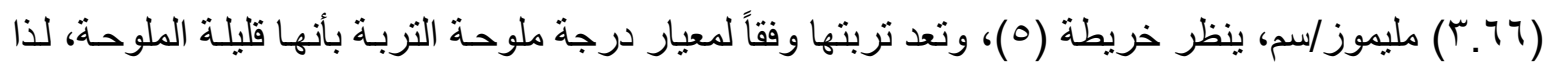
فهي تتميز بانخفاض نسبة الأملاح في تربتها على الرغم من إرتفاع نسبة الملوحة لبعض المناطق، وان سبب لهب

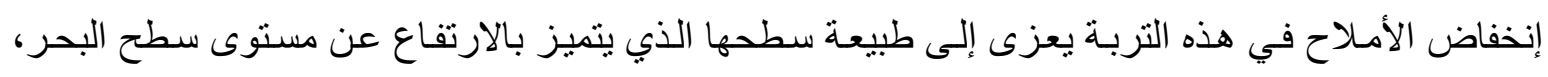
فضـلاً عن إن الميـاه السطحية لا تضـيف كميـات كبيرة مـن الملوحسة مدـا أدى إلى قلـة الأمـلاح في تربتهـا، وتتوزع قيم لملوحة بحسب الأعماق المدروسة كما يأتي:

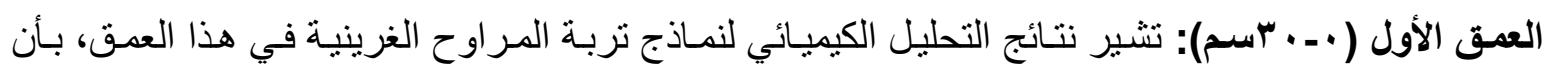

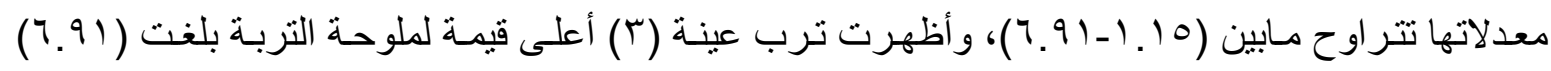
مليموز/سم، في حين كانت أقل قيمة لملوحة التربة في ترب عينة ( (1) بلغت (10 ـ ( ) مليموز/سم، ويعود سبب تباين قيم الملوحة إلى تباين مستويات السطح بين مو اقع هذه التربة، ينظر ملحق (V). 


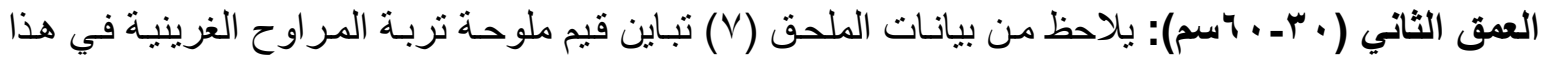

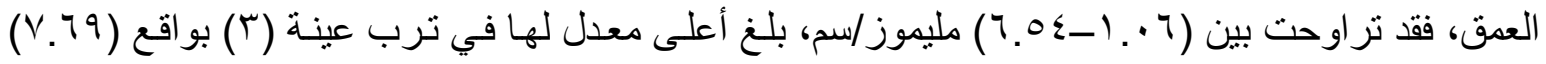
مليموز/سم، في حين بلغ أدنى معدل لها في ترب عينة ( () بو اقع ( ( إ. مليموز /سم.

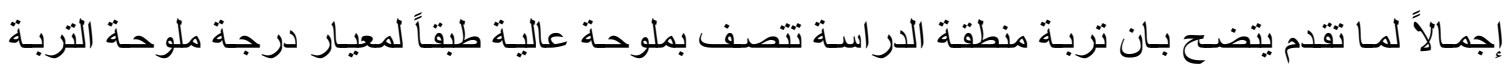
الموضح في جدول (Y) حيث بلغ معدلها العام لجميع مو اقع الترب ولكلا العمقين (Tr. • ( ) مليموز /سم، ولقد تبين من خـلال الدر اسـة الميدانيـة إن هنالك الكثير من أراضـي قضـائي بدرة و الحي وبشكل خـاص أر اضـي الأحو اض تعاني من درجات ملوحة شديدة وشديدة جداً، ويمكن إرجاع سبب ذلك إلى ارتفاع درجات الحرارة وقلة تساقط الأمطار التي تعمل على غسل الأملاح في الطبقات العليا وتخليص التربـة منها مـع نشـاط الخاصية الثعرية التي تعمل على نقل الأملاح إلى الآفاق العليا للترب.

الاستتنتاجات:

$$
\text { إن من أهم النتائج التي توصل إليها البحث هي ما يأتي: }
$$

ا ـ كان للانحدار التدريجي لسطح الأرض في بعض أجز اء منطقة الدراسـة أثر في رداءة تصـريف الميـاه بشكل عام مع وجود تباينات مكانية تتبع انحدار السطح التدريجي بين مناطق كتوف الأنهار وأحو اض الأنهار عن مجرى النهر ممـا أدى إلى اختلاف خصـائص التربـة في منـاطق كتوف الأنهار عن منـاطق أحسو اض الأنهار، وقد أدى هذا الانحدار البسيط إلى نر اكم المياه الزائدة في مناطق أحواض الأنهار وعدم تصريفها ممـا

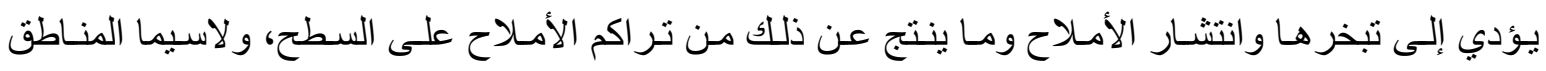
الواقعة شرق وغرب خط الارتفاع (ع (متر) الذي يعد أكثر مناطق الدراسة تركز للملوحة.

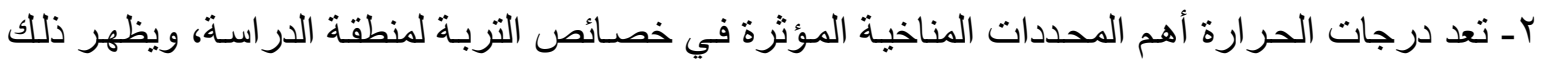
جلياً في زيادة خطر التملح، حيث إن درجات الحرارة كأحد العناصر المناخيـة تعد من الأسباب الرئيسية في حدوث مشكلة التملح وتز ايدها، كما إن إتجاه درجات الحرارة الصـاعد في منطقة الدراسـة من شـأنه أن يزيد من مشكلة التملح وخاصة في الجهات الثرقية و الجنوبية لقضاء الحي. ז- أن كمية الأمطار الساقطة في منطقة الدر اسة قليلة إذ بلغ المعدل السنوي لها (؟. با ملم) وهي غير كافية لإتمام عملية غسل التربة مما يزيد من كمية الأملاح في التربة سنة بعد أخرى. ب- يتبين من خلال الدراسة إرتفاع قيم التبخر/النتح وتسجيلها إلى معدلات مرتفعة خلال فصل الصيف إذ تبلغ

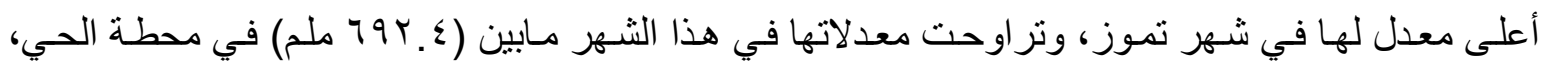

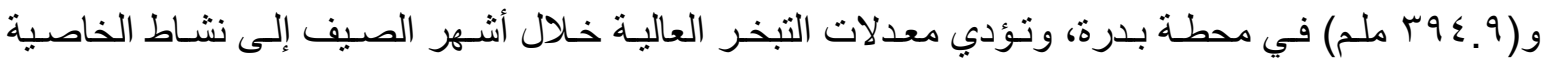
الثعرية للتربة وصعود المياه الجوفية على سطح التربة و العمل على زيادة تملحها بشكل مستمر.

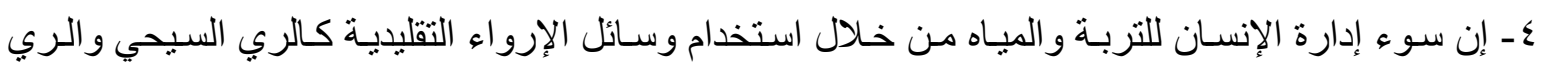

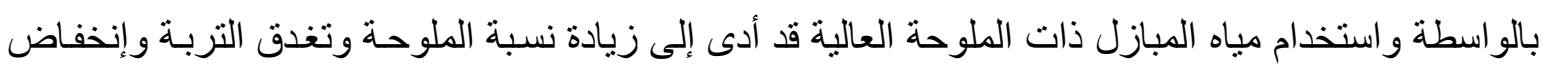


ا ـ ضرورة وجود نظام لرصد التغيرات التي تحدث في التربـة والمياه و التـي من ضمنها ملوحة التربـة ومياه

الري ومستوى المياه الجوفية وإنتاجية الأرض مع استعمال التقنيات و الوسائل الحديثة لرصد هذه التغيرات.

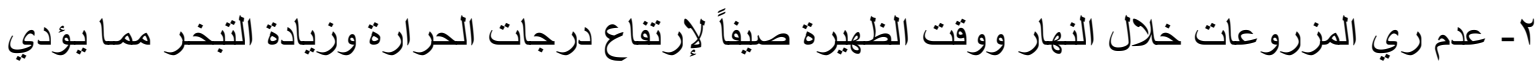
إلى ارتفاع الأملاح عن طريق الخاصية الثعرية مما يؤدي إلى تلف المزروعات. r- عدم استعمال مياه المبازل للإرواء، وذلك لوجود نسبة عالية من الأمـاح في بعضـها، وهذه النسب تزيد

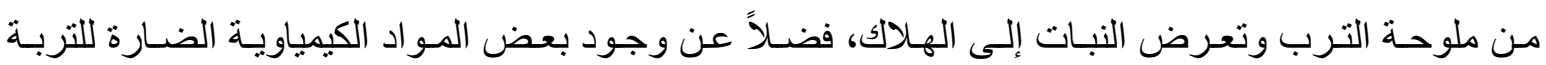
و المقللة لإنتاجيتها. ع - ضـرورة التأقلم (Adaptation) مـع التغيرات المناخيـة المتوقع حدوثها وتز ايدـ وتيرتها في المستقبل، وذللك من خـلال التعـاون مـع العديد من الجهات لدر اسـة آليـات هذا التأقلم عن طريـق أستنباط أصناف مـن المحاصيل الزر اعية يمكنها تحمل الظروف المناخيـة الناتجـة عن تغير المنـاخ مثل زيادة ملوحـة التربـة، وقلـة الموارد المائية، وإرتفاع درجات الحرارة...إلخ. هـ استخدام طريقة الري بالتتقيط أو الرش للمحاصيل الزر اعية التي لا تحتاج إلى كميات كبيرة من المياه لقليل استهلاك كميات كبيرة من المياه وتقليل نسبة التملح في التربة.

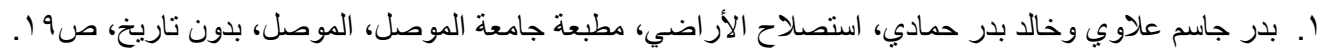

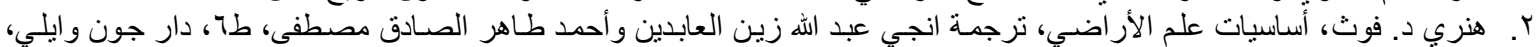

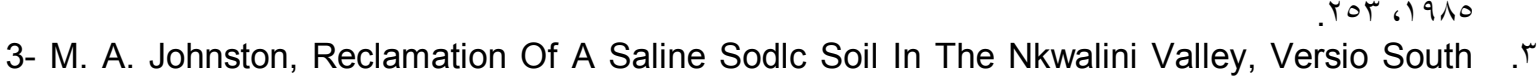
African Association, June, 1977, p42.

4- Buring, Soil and Soil Conditions in Iraq, Republic of Iraq, Ministry of Argriculture, Baghdad, 1960, p87.

•. فليح حسن الطائي، طرق و أسـاليب التنبؤ بتحول الأر اضـي إلى الملحية و القلويـة في العر اق، المنظمـة العربيـة للتنميـة الزر اعية، ندوة

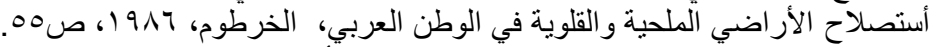

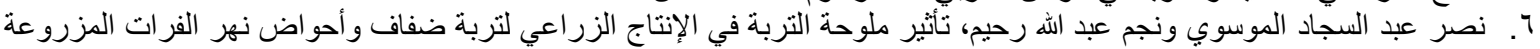

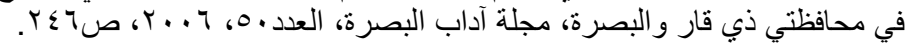

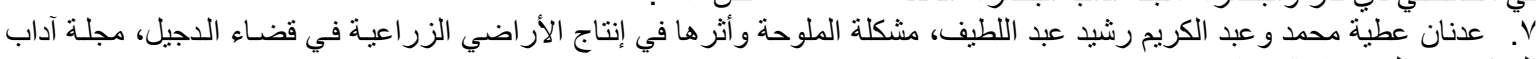

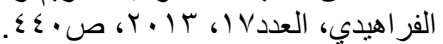

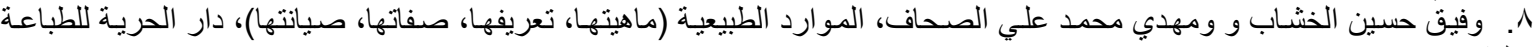

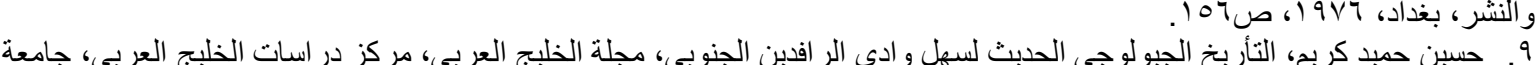

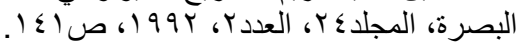

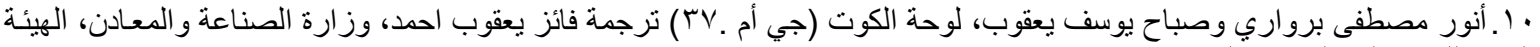

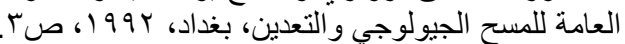

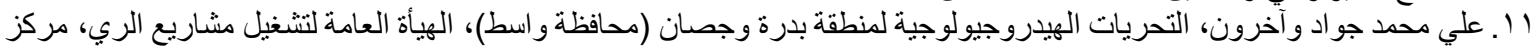

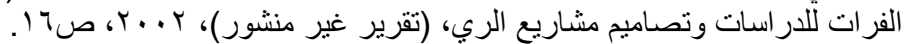

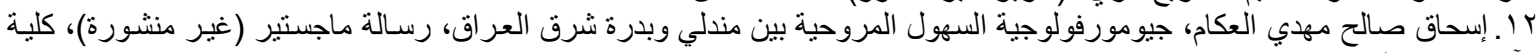

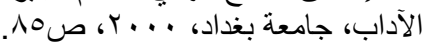

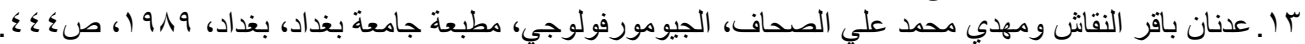
ـ ا ـ محمد جعفر جواد السامر ائي، الأنهار الحدودية في محافظة واسط، رسالة ماجستير (غير منشورة)، كلية الآداب، جامعة بغدادة،

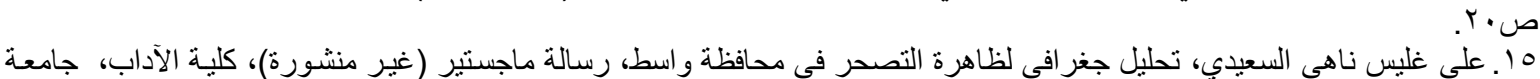

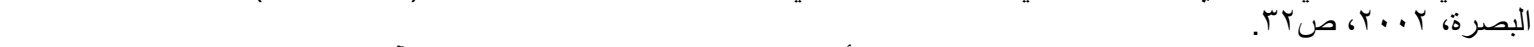

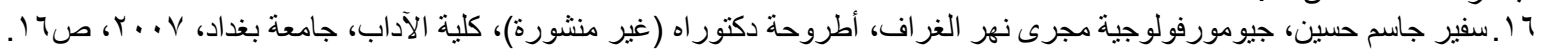

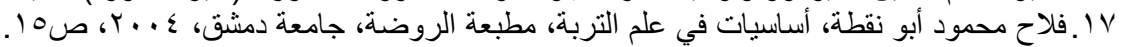

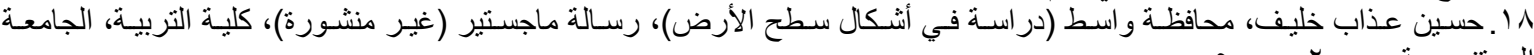


19- Forat Haider And Abdul Rahman Jassim, The Soil Of West Gharraf Project, General Organization For Soil And Land Reclamation, Baghdad, Iraq,1992, P4.

• ץ. داود جاسم الربيعي، من خصائص التربة في محافظة البصرة، موسوعة البصرة الحضارية، المحور الجغر افي، مطبعة جامعة البصرة، . اب. طلال مريوش جاري اللامي، أشكال سطح الأرض لنهر دجلة بين العزيزية والكوت، أطروحة دكتور اه (غير منشورة)، كلية الآداب،

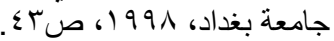

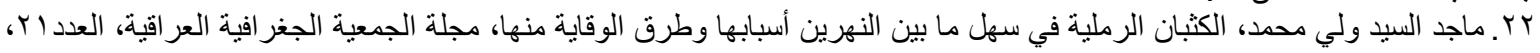
.VV (19NV

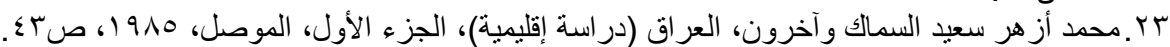

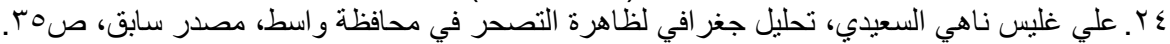

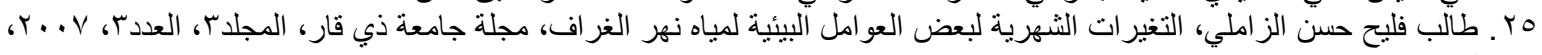

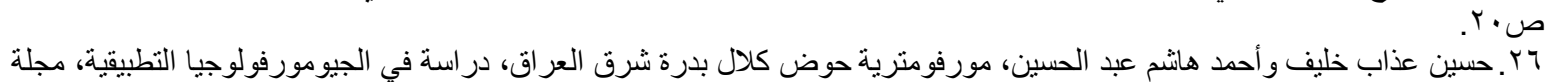

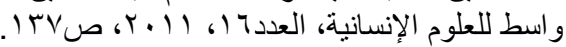

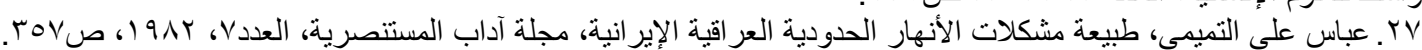

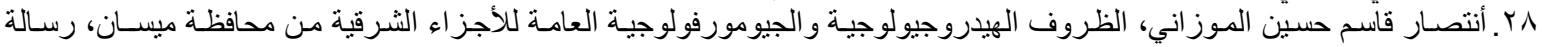

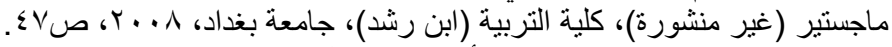

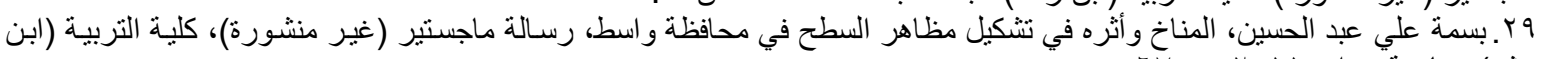

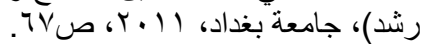

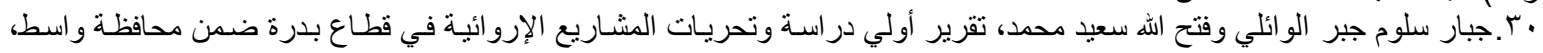

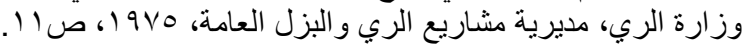

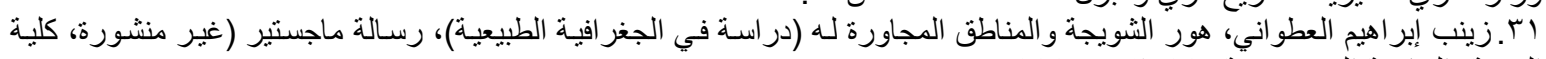

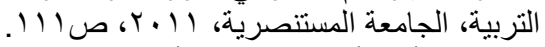

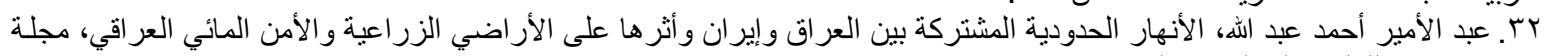

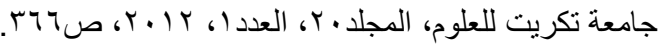

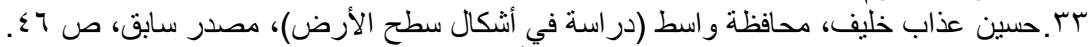

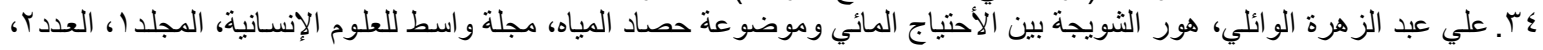

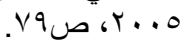

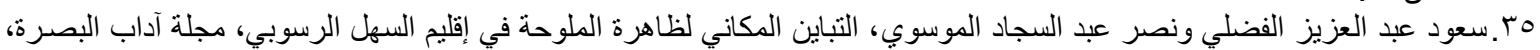

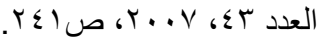

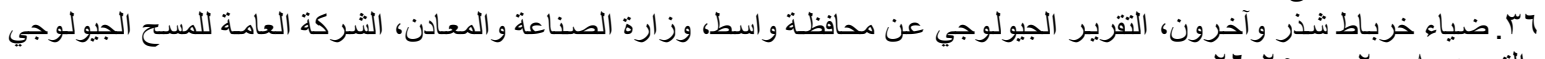

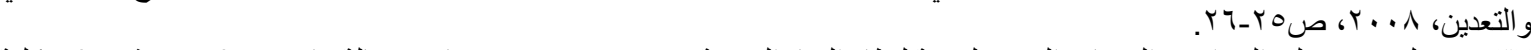

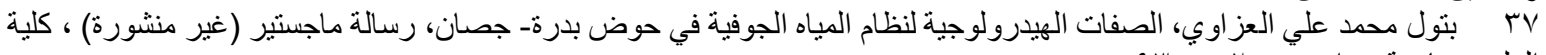

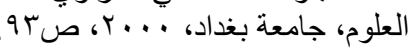

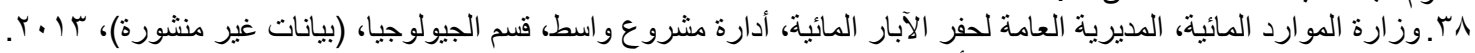

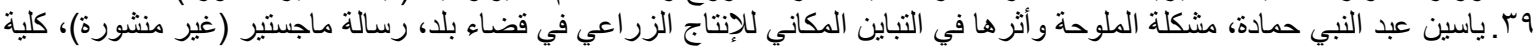

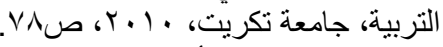

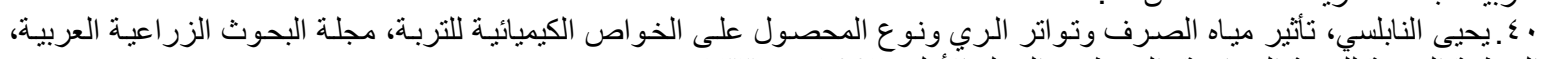

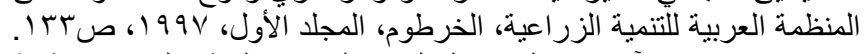

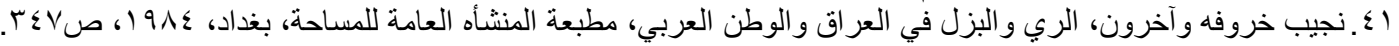

41- Virgil L. Backlund Ronald R. Hoppes, Status Of Soil Salinity In California, The Institute For Agriculture In California, October, 1984, P 8-9.

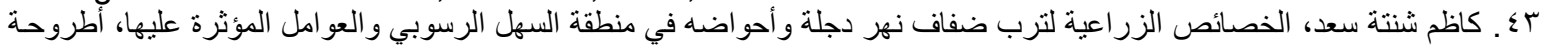

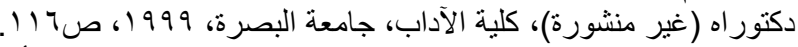

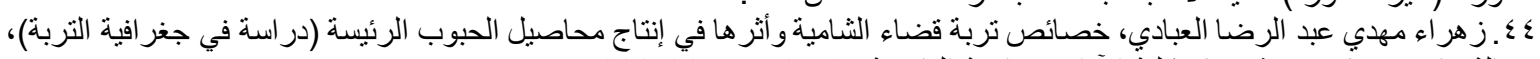

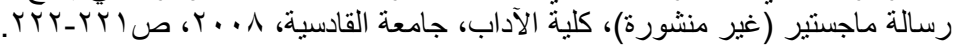

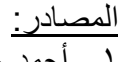

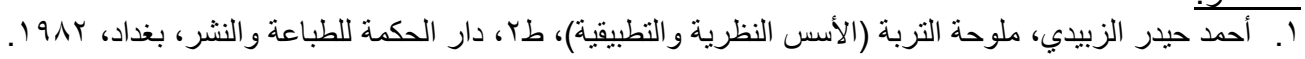

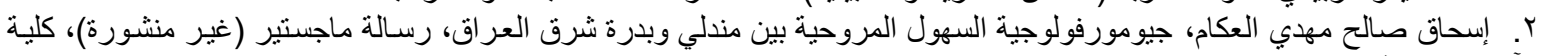

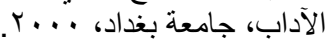

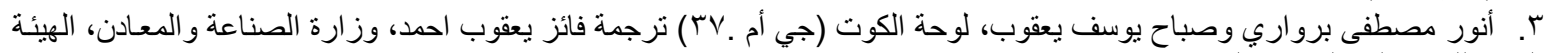

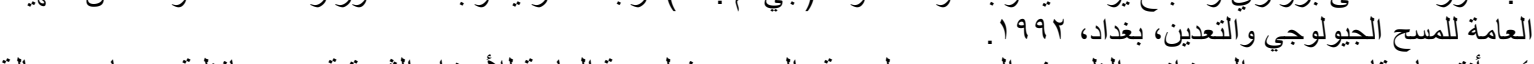

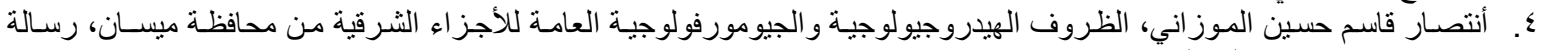

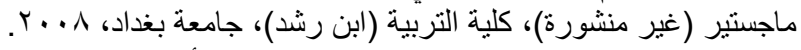

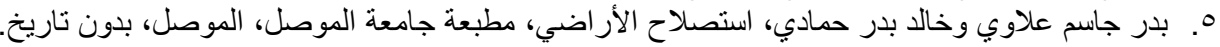

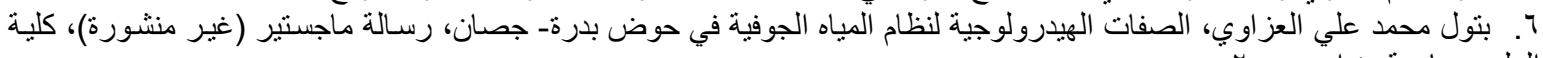

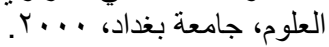

V. بسمة علي عبد الحسين، المناخ و أثره في تثكيل مظاهر السطح في محافظة واسط، رسالة ماجستير (غير منشورة)، كلية التربية (ابن

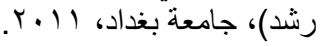

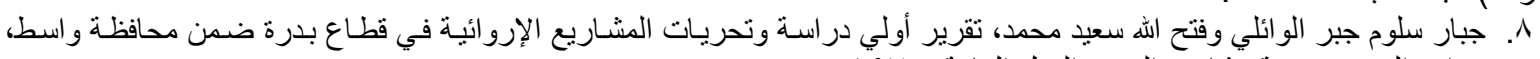

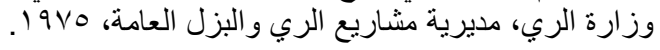




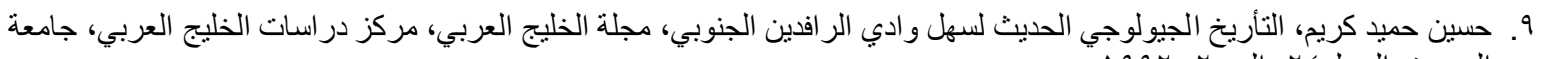

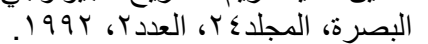

ا. حسين عذاب خليف، محافظة واسط (در اسـة في أشنكال سطح الأرض)، رسـالة ماجستير (غير منشورة)، كليـة التربيـة، الجامعـة

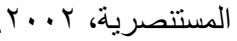

ال. حسين عذاب خليف وأحمد هانشم عبد الحسين، مورفومترية حوض كلال بدرة شرق العراق، دراسـة في الجيومورفولوجيا التطبيقية،

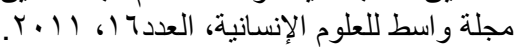

r ا. داود جاسم الربيعي، من خصائص الإنية التربة في محافظة البصرة، موسوعة البصرة الحضارية، المحور الجغر افي، مطبعة جامعة البصرة، .1911

r ا. . حسين كريم حمد الساعدي، هيدرولوجية أهور الدلمج والثويجة والسعدية وبيئاتها الحيوية، أطروحة دكتور اه (غبر منشورة)، كلية

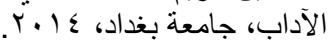

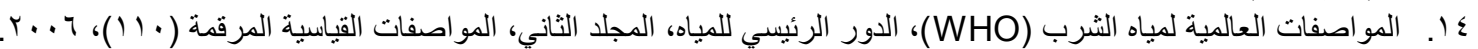

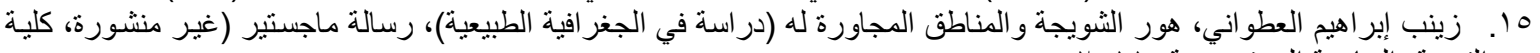

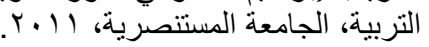

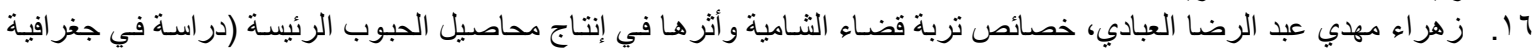

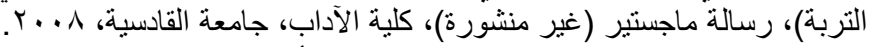

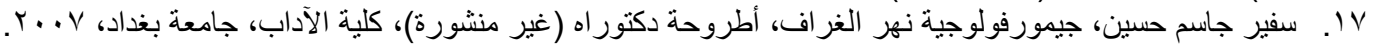

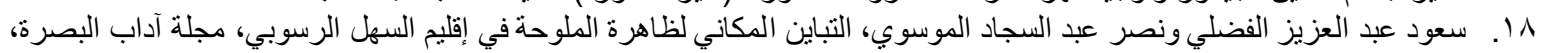

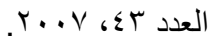

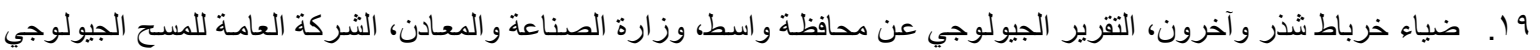

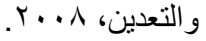
• r. طلال مريوش جاري رئ اللامي، أشكال سطح الأرض لنهر دجلة بين العزيزية والكوت، أطروحة دكتور اه (غير منشورة)، كلية الآداب،

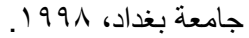

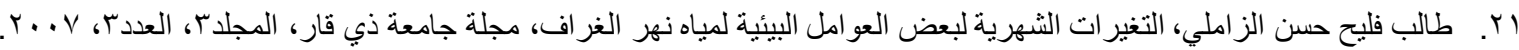

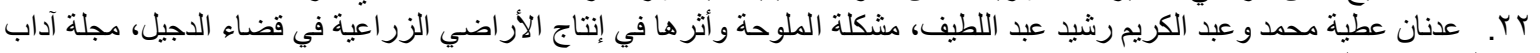

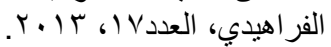

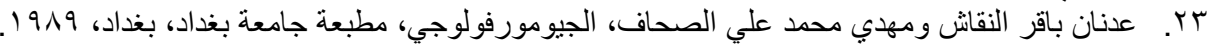

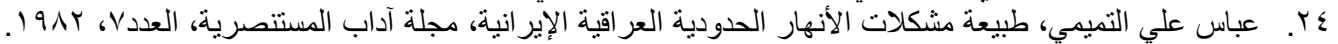

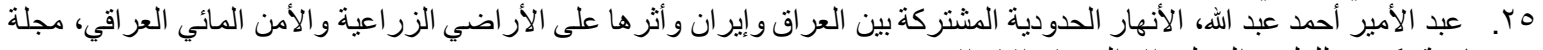

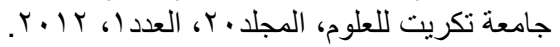
جr. على عبد الزهرة الو ائلي، هور الثويجة بين الأحتباج المائي وموضوعة حصاد المياه، مجلة واسط للعلوم الإنسانية، المجلد ا، العدد؟، V.r. علي غليس ناهي السعيدي، تحليل جغر افي لظاهرة التصحر في محافظة واسط، رسالة ماجستير (غير منشورة)، كلية الآداب، جامعة

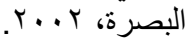

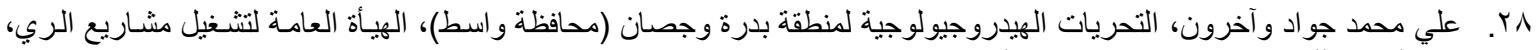

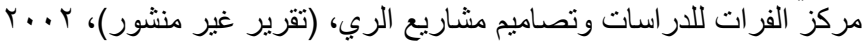

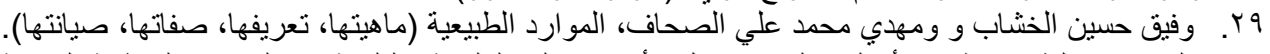

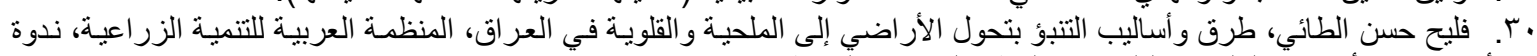

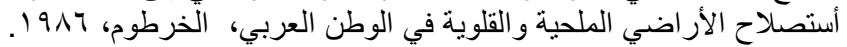

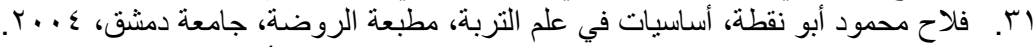

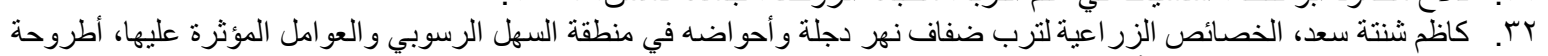

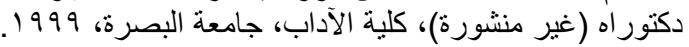

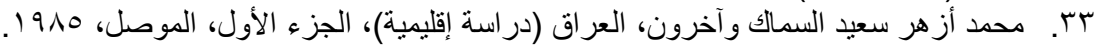

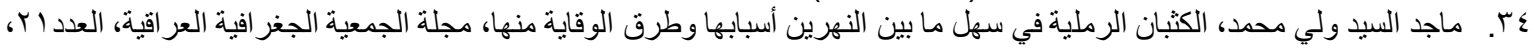
$.191 \mathrm{~V}$

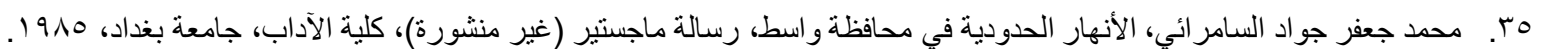

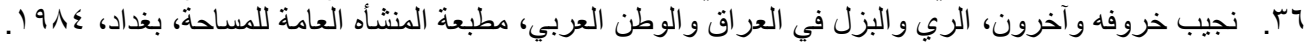

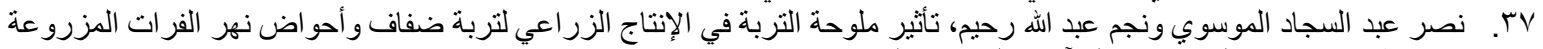

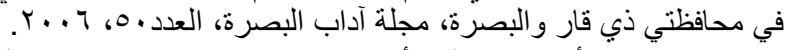

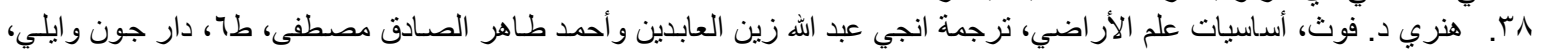
1910 qr. ياسين عبد النبي حمادة، مشكلة الملوحة و أثر ها في التباين المكاني للإنتاج الزراعي في قضاء بلد، رسالة ماجستير (غير منشورة) كلية

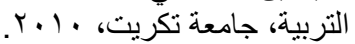

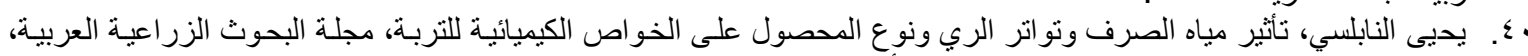

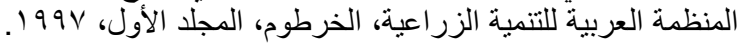

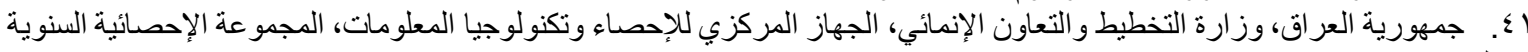

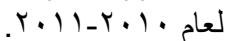

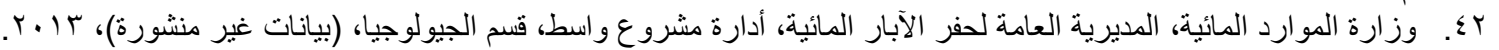

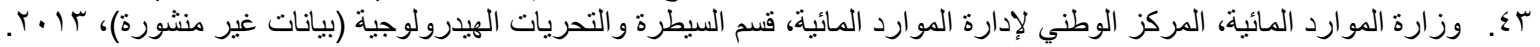

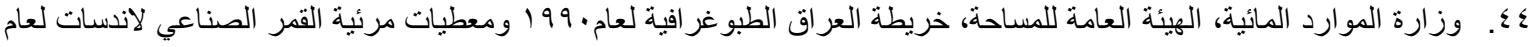




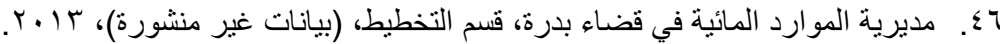

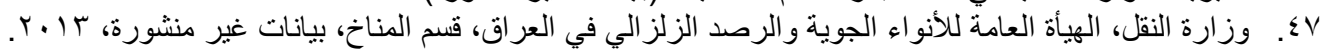

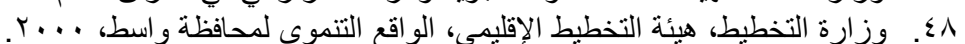

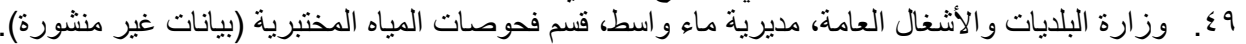

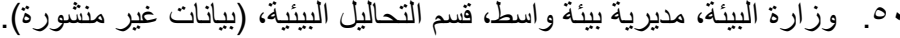

51- Buring, Soil and Soil Conditions in Iraq, Republic of Iraq, Ministry of Argriculture, Baghdad, 1960.

52- Forat Haider And Abdul Rahman Jassim, The Soil Of West Gharraf Project, General Organization For Soil And Land Reclamation, Baghdad, Iraq,1992.

53- Fao Unesco, Irrigation Drainage, Salinity , An International Source, Book London, Hutchin Son, Aelco, 1973.

54- M. A. Johnston, Reclamation Of A Saline Sodlc Soil In The Nkwalini Valley, Versio South African

Association

June,

1977.

55- Virgil L. Backlund Ronald R. Hoppes, Status Of Soil Salinity In California, The Institute For Agriculture In California, October, 1984.

الملاحق:

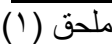

معيار منظمة الصحة الدولية (WHO) لمياه الثرب و الاستخدامات الأخرى

\begin{tabular}{|c|c|c|c|c|c|c|c|c|c|}
\hline Turbidity & $\begin{array}{c}-\mathrm{CL} \\
\mathrm{mg} / \mathrm{l}\end{array}$ & $\begin{array}{l}{ }^{+} \mathrm{Na} \\
\mathrm{mg} / \mathrm{l}\end{array}$ & $\begin{array}{l}{ }^{+} \mathrm{Mg} \\
\mathrm{mg} / \mathrm{l}\end{array}$ & $\begin{array}{l}{ }^{+} \mathrm{Ca} \\
\mathrm{mg} / \mathrm{l}\end{array}$ & $\mathrm{HCO} 3$ & $\mathrm{CO} 3$ & $\begin{array}{l}\text { E.C } \\
\text { s/m }\end{array}$ & $\mathrm{PH}$ & فحوصــــــات \\
\hline r.o & r.. & rT. & 0 . & vo & $7 .$. & $0 \leqslant$ & $1 \ldots$ & A.O-V.T & درجتها \\
\hline
\end{tabular}

المصدر: المواصفات العالمية لمياه الثرب (WHO)، الأبور الرئيسي للمياه، المجلا الثاني، المواصفات القياسية المرقمة

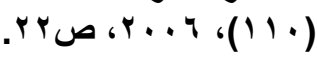

ملحق (Y) التباين المكاني لمعدلات الملوحة (ES) في تربة كتوف الأنهار لمنطقة الدراسة

\begin{tabular}{|c|c|c|c|}
\hline 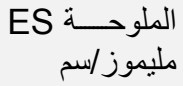 & العمق (سم) & رقم العينة & الوحدات الإدارية \\
\hline 9.00 & $r \cdot \ldots \cdot$ & \multirow{3}{*}{ S 1} & \multirow{9}{*}{ مركز قضاء الحي } \\
\hline ᄉ. $\cdot 1$ & T._r. & & \\
\hline$\lambda . \wedge Y$ & المعدل & & \\
\hline$r . \leqslant 7$ & $r \cdot{ }^{\prime} \cdot$ & \multirow{3}{*}{ S 2} & \\
\hline r. ro & T.-Y. & & \\
\hline r.r. & المعدل & & \\
\hline 7.01 & معدل العمق ·-·r & \multirow{3}{*}{ المعدل } & \\
\hline $0.7 \mathrm{~V}$ & معدل العمق •r-. & & \\
\hline 7.99 & المعدل العام & & \\
\hline 1.90 & $r \cdot \ldots \cdot$ & \multirow{3}{*}{ S 1} & \multirow{9}{*}{ ناحية الموفقية } \\
\hline$\Lambda . Y \leq$ & T._T. & & \\
\hline 1. 7. & المعدل & & \\
\hline$r . r$ & $r \cdot{ }^{\prime} \cdot$ & \multirow{3}{*}{ S 2} & \\
\hline$r .90$ & T.-Y. & & \\
\hline$r .99$ & المعدل & & \\
\hline 0.99 & معدل العمق ·_-r & \multirow{3}{*}{ المعدل } & \\
\hline 0.7. & معدل العمق. r-_. & & \\
\hline $0 . \wedge$. & المعدل العام & & \\
\hline 7.10 & معدل العمق ·_-·r & & \multirow{3}{*}{ المعدل العام } \\
\hline $0.7 \varepsilon$ & معدل العمق •r-_. & & \\
\hline 0.90 & المعدل العام & & \\
\hline
\end{tabular}

المصدر : الباحث أعتماداً على:-

1 - جامعة و اسط، كلية الزر اعة،، مختبر ات أبحاث التربة و المو ارد المائية.

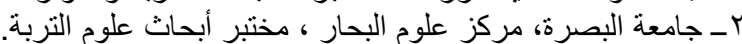

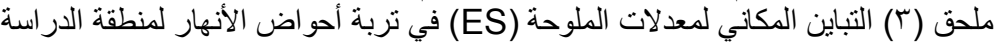




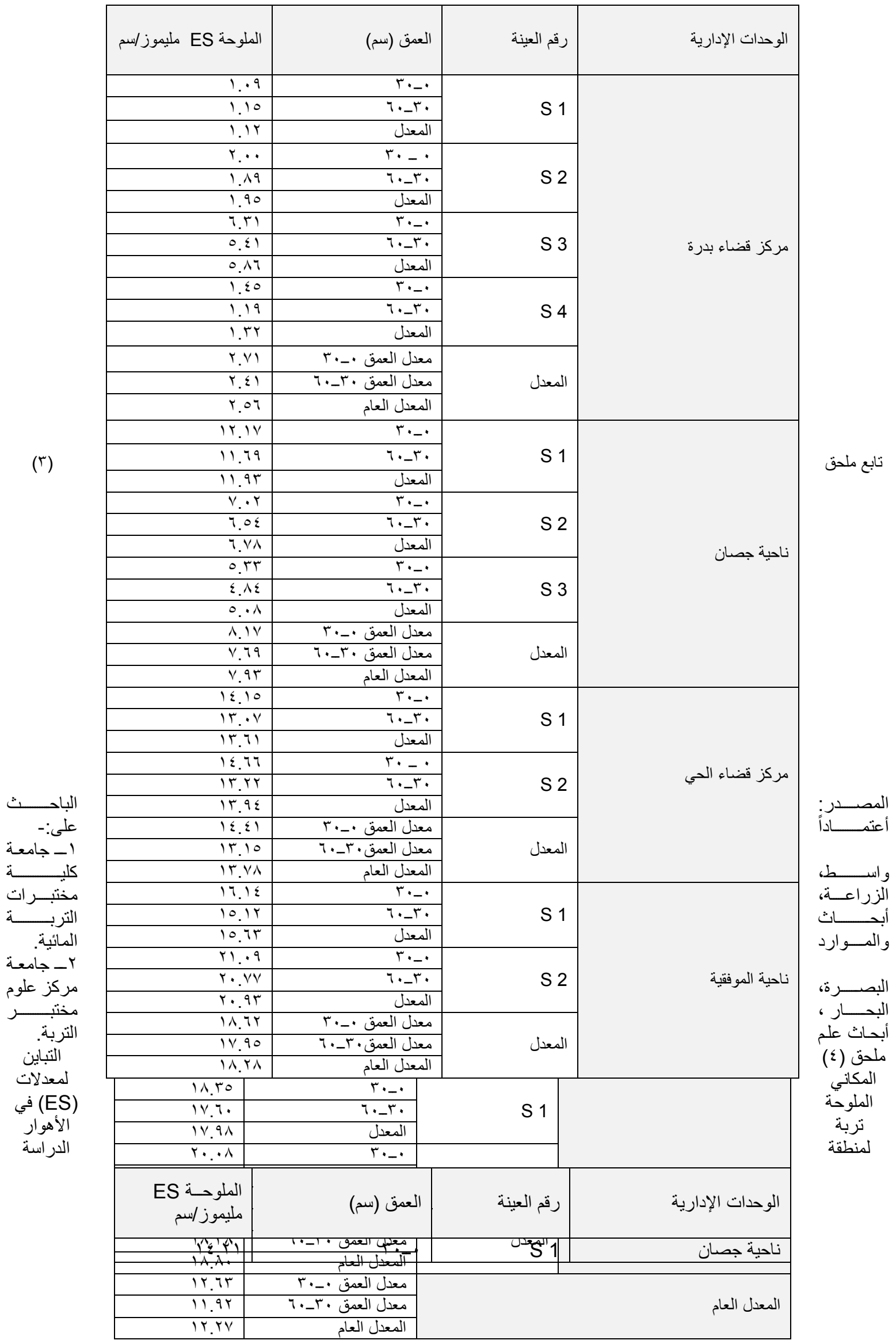




\begin{tabular}{|c|c|c|c|}
\hline$|r . V|$ & T._T. & & \\
\hline 17.97 & المعدل & & \\
\hline $1 . .10$ & $r \cdot{ }^{\prime} \cdot$ & \multirow{3}{*}{ S 2} & \\
\hline $9.0 Y$ & T._r. & & \\
\hline $9 . \wedge \varepsilon$ & المعدل & & \\
\hline$|\leq . Y|$ & $r \cdot \ldots \cdot$ & \multirow{3}{*}{ S 3} & \\
\hline 11.0 & T._r. & & \\
\hline 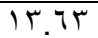 & المعدل & & \\
\hline $0 . Y_{1}$ & r._. & \multirow{3}{*}{ S 4} & \\
\hline $0 . \Sigma Y$ & T._r. & & \\
\hline $0 . r T$ & المعدل & & \\
\hline 1.90 & معدل العمق ·-_r & \multirow{3}{*}{ المعدل } & \\
\hline $1 \cdot . \leqslant r$ & معدل العمق.r-_. & & \\
\hline $1 \cdot .79$ & المعدل العام & & \\
\hline $1 Y .71$ & $r \cdot{ }^{\prime} \cdot$ & \multirow{3}{*}{ S 1} & \multirow{12}{*}{ ناحية الموفقية } \\
\hline $1 Y .0$ & T._r. & & \\
\hline IT.rV & المعدل & & \\
\hline $1 \cdot . \leqslant V$ & $r \cdot-\cdot$ & \multirow{3}{*}{ S 2} & \\
\hline $1 \cdot .99$ & T._r. & & \\
\hline $1 \cdot . \mathrm{YA}$ & المعدل & & \\
\hline 11.01 & معدل العمق ·_-"r & \multirow{3}{*}{ المعدل } & \\
\hline 11.28 & معدل العمق."r_. & & \\
\hline $11 . r \mu$ & المعدل العام & & \\
\hline $11 . \mathrm{KV}$ & معدل العمق ·-_"r & \multirow{3}{*}{ المعدل العام } & \\
\hline $1 . .10$ & 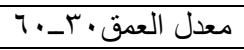 & & \\
\hline 11.11 & المعدل العام & & \\
\hline
\end{tabular}

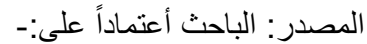

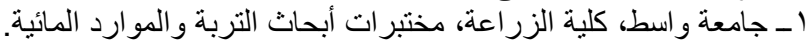

Y- جامعة البصرة، مركز علوم البحار ، مختبر أبحاث علوم التربة التربة.

ملحق (0) التباين المكاني لمعدلات الملوحة (ES) في تربة المستتقعات لمنطقة الدراسة

\begin{tabular}{|c|c|c|c|}
\hline الملوحسـة ES اسم & العمق (سم) & رقم العينة & الوحدات الإدارية \\
\hline YY.VO & r._. & \multirow{3}{*}{ S 1} & \multirow{9}{*}{ مركز قضاء الحي } \\
\hline YY.IE & T._r. & & \\
\hline YY. $\leqslant 0$ & المعدل & & \\
\hline$r \leqslant .10$ & $r \cdot{ }^{\prime} \cdot$ & \multirow{3}{*}{ S 2} & \\
\hline YI.OV & T._r. & & \\
\hline YY.AT & المعدل & & \\
\hline YT. $\leqslant 0$ & معدل العمق •-.•r & \multirow{3}{*}{ المعدل } & \\
\hline YI.^T & معدل العمق."r-.T & & \\
\hline YY.TT & المعدل العام & & \\
\hline 19.11 & $r \cdot \ldots \cdot$ & \multirow{3}{*}{ S 1} & \multirow{9}{*}{ ناحية البشائر } \\
\hline IN.Y. & T._r. & & \\
\hline 11.77 & المعدل & & \\
\hline$r . .70$ & $r \cdot{ }^{\prime} \cdot$ & \multirow{3}{*}{ S 2} & \\
\hline YA.TY & T._r. & & \\
\hline rq. 29 & المعدل & & \\
\hline$Y \varepsilon . \wedge \wedge$ & معدل العمق •-.•r & \multirow{3}{*}{ المعدل } & \\
\hline YT.YT & معدل العمق.r-r.T & & \\
\hline$r \varepsilon . A$ & المعدل العام & & \\
\hline TE.IV & معدل العمق ·-_r & & \multirow{3}{*}{ المعدل العام } \\
\hline YY.0T & معدل العمق.r._. & & \\
\hline rT.TV & المعدل العام & & \\
\hline
\end{tabular}

المصدر: الباحث أعنماداً على:-

ا ـ جامعة واسط، كلية الزر اعة، مختبر ات أبحاث التربة و المو ارد المائية. 
r بامعة البصرة، مركز علوم البحار ، مختبر أبحاث علوم التربة. ملحق (T) التنبان المكاني لمعدلات الملوحة (ES) في تربة الكثبان الرملية لمنطقة الدراسة

\begin{tabular}{|c|c|c|c|}
\hline 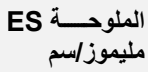 & العمق (سم) & رقم العينة & الوحدات الإدارية \\
\hline $7 . Y \wedge$ & $r \cdot . \cdot$ & \multirow{3}{*}{ S 1} & \multirow{9}{*}{ ناحية الموفقية } \\
\hline 7.19 & r. r. & & \\
\hline $7 . Y \leq$ & المعدل & & \\
\hline$\leqslant . \leqslant 7$ & r. . . & \multirow{3}{*}{ S 2} & \\
\hline$\varepsilon . Y V$ & T.-r. & & \\
\hline$\varepsilon . r V$ & المعدل & & \\
\hline $0 . r v$ & معدل العمق •-."r & \multirow{3}{*}{ المعدل العام } & \\
\hline $0 . r T$ & معدل العقق ·r_. & & \\
\hline $0 . r$. & المعدل العام & & \\
\hline
\end{tabular}

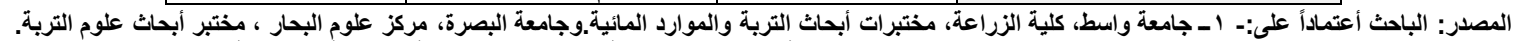
ملحق (V) التباين المكاني لمعدلات الملوحة (ES) في تربة المراوح النغرية النغية لمنطقة الدراسة

\begin{tabular}{|c|c|c|c|}
\hline الملوحســ ES مليموز/سم & العمق (سم) & رقم العينة & الوحدات الإدارية \\
\hline 1.10 & r._. & \multirow{3}{*}{ S 1} & \multirow{15}{*}{ ناحية زرباطية } \\
\hline 1.9 & I._T. & & \\
\hline 1.11 & المعدل & & \\
\hline 1.07 & r. - . & \multirow{3}{*}{ S 2} & \\
\hline 1.9 & ר._r. & & \\
\hline חוז 1. & المعدل & & \\
\hline 7.91 & r... & \multirow{3}{*}{ S 3} & \\
\hline $7.0 \leq$ & T._r. & & \\
\hline $7 . V T$ & المعدل & & \\
\hline $0 . V Y$ & r... & \multirow{3}{*}{ S 4} & \\
\hline $0 . Y \leqslant$ & צ._r. & & \\
\hline $0 . \leqslant 1$ & المعدل & & \\
\hline$\Gamma . \wedge \varepsilon$ & معدل العمق •-"r & \multirow{3}{*}{ المعدل العام } & \\
\hline$r \leqslant \Lambda$ & معدل العمق."r-. & & \\
\hline T.77 & المعدل العام & & \\
\hline
\end{tabular}

المصدر: الباحث أعتماداً على:-

1- جامعة واسط، كلية الزراعة، مختبرات أبحاث التربة والموارد المائية.

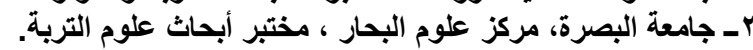

